
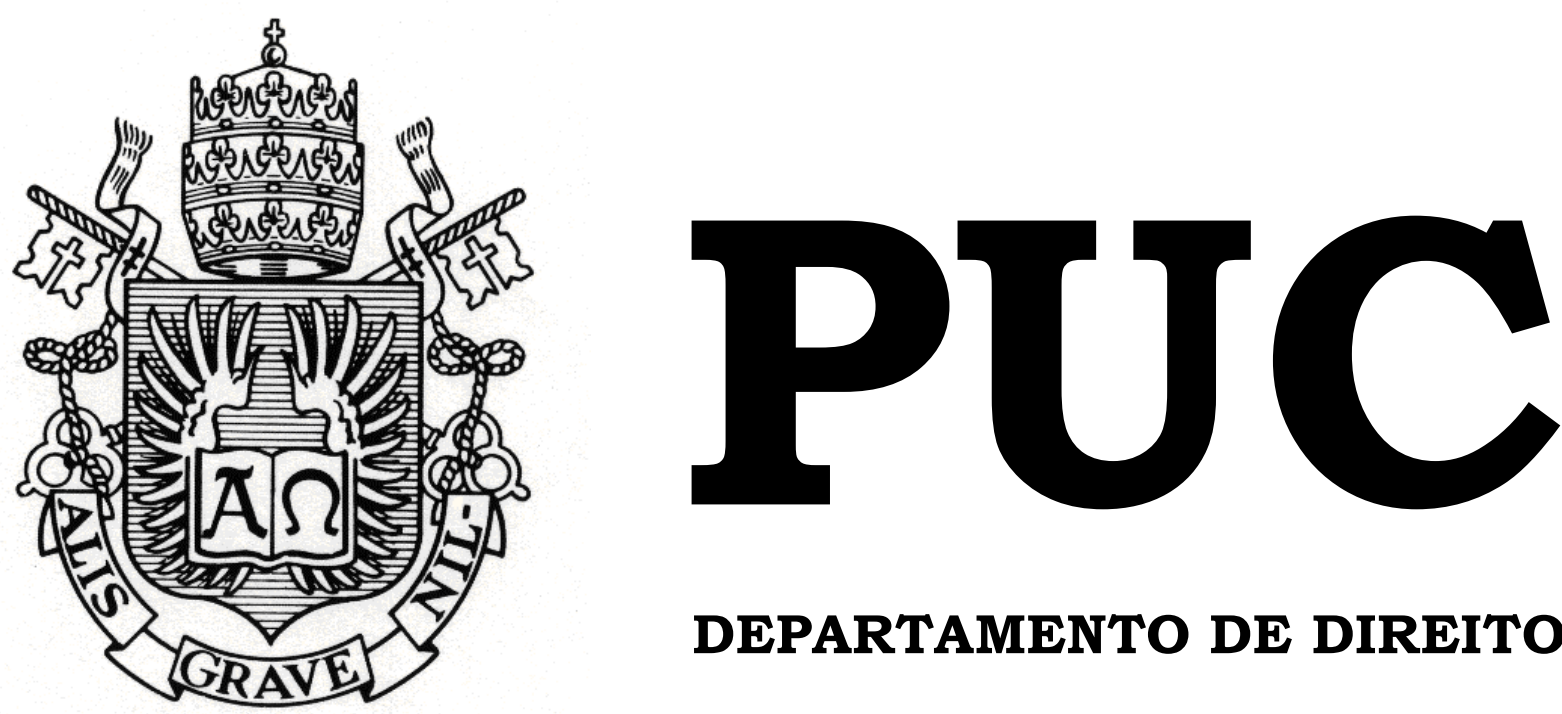

DEPARTAMENTO DE DIREITO

\title{
TAXA DE OCUPAÇÃO POR USO EXCLUSIVO DE IMÓVEL NA SEPARAÇÃO DE FATO: UMA INTERPRETAÇÃO SISTEMÁTICA DO DIREITO POSITIVO VIGENTE
}

por

FERNANDA SERPA MESQUITA

ORIENTADORA: INÊSS ALEGRIA ROCUMBACK

PONTIFÍCIA UNIVERSIDADE CATÓLICA DO RIO DE JANEIRO

RUA MARQUÊS DE SÃO VICENTE, 225 - CEP 22453-900

RIO DE JANEIRO - BRASIL 


\section{TAXA DE OCUPAÇÃO POR USO EXCLUSIVO DE IMÓVEL NA SEPARAÇÃO DE FATO: UMA INTERPRETAÇÃO SISTEMÁTICA DO DIREITO POSITIVO VIGENTE}

por

FERNANDA SERPA MESQUITA

Monografia apresentada ao Departamento de Direito da Pontificia Universidade

Católica do Rio de Janeiro (PUC-Rio) para a obtenção do Título de Bacharel em Direito.

Orientadora: Inês Alegria Rocumback 
"Teu dever é lutar pelo Direito. Mas no dia em que encontrares o Direito em conflito com a Justiça, luta pela Justiça."

(Eduardo Couture)

"Nunca se esqueça do lugar em que você parte, mas deixe esse lugar e junte-se ao mundo."

(Michel Serres) 


\section{AGRADECIMENTOS}

Em primeiro e especial lugar, à minha família, que nunca mediu, esforços para me apoiar e me motivar nessa minha trajetória acadêmica, assim como nos demais aspectos da minha vida.

À Professora e orientadora Inês Alegria Rocumback, por sua disposição e atenção, sempre com muita cordialidade e paciência, contribuindo para a conclusão deste trabalho de monografia.

Aos demais mestres do curso de Direito da PUC-Rio através dos quais pude assimilar valiosos conhecimentos.

Aos meus amigos, fiéis companheiros, pessoas com as quais tenho a sorte de poder sempre contar e de aprender.

Por fim, mas não menos importante, ao meu namorado, Eduardo Lima Mauad, por ser minha inspiração diária, alguém que muito admiro e quero sempre por perto. 


\section{RESUMO}

O presente trabalho tem por objetivo expor a tese que defende o direito à taxa de ocupação por uso exclusivo de imóvel durante a separação de fato, com base em uma interpretação sistemática da lei, de forma a se evitar o enriquecimento sem causa do cônjuge que se utilizou privativamente do imóvel de co-propriedade do ex-consorte, impedindo este de plenamente exercer seu direito de propriedade.

Apesar de a lei não prever expressamente, sustenta-se seja considerado o fim do regime patrimonial e do consequente estado de mancomunhão dos bens do ex- casal a partir da data da separação de fato, por esta refletir a ausência dos motivos que os justificavam quando da constância do casamento, quais sejam: a união de vida e de interesses e a mútua contribuição patrimonial. Dessa forma, passam a ser aplicáveis as regras de condomínio, tornando viável a cobrança da taxa de ocupação por uso exclusivo de imóvel durante a separação de fato.

Esta monografia, portanto, buscou promover uma contribuição ao estudo da separação de fato, dando enfoque a um de seus desdobramentos jurídicos, isto é, analisando a sua relação com a taxa de ocupação por uso exclusivo de imóvel, com o olhar crítico voltado para a orientação jurisprudencial sobre o assunto e para o papel do Poder Judiciário.

Palavras-chave: separação de fato - taxa de ocupação por uso exclusivo de imóvel - enriquecimento sem causa - mancomunhão - regime de bens condomínio - interpretação sistemática - Poder Judiciário - Justiça. 


\section{SUMÁRIO}

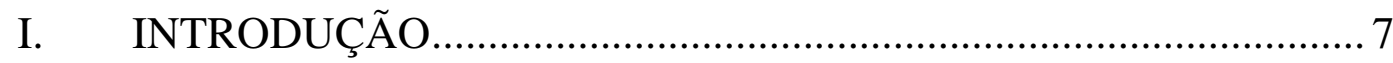

II. EVOLUÇÃO LEGISLATIVA DA DISSOLUBILIDADE DO

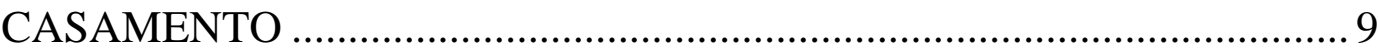

III. CONCEITO JURÍDICO DA SEPARAÇÃO DE FATO ...................... 17

IV. SEPARAÇÃO DE FATO: UMA REALIDADE À MARGEM DO

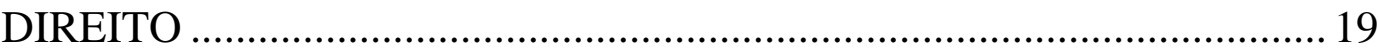

V. DA APLICABILIDADE DA TAXA DE OCUPAÇÃO POR USO EXCLUSIVO DE IMÓVEL NA SEPARAÇÃO DE FATO ..........................25

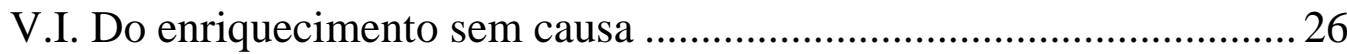

V.II. Mancomunhão e condomínio: dois institutos jurídicos distintos ....29

V.III. Da necessidade de uma interpretação sistemática e teleológica da

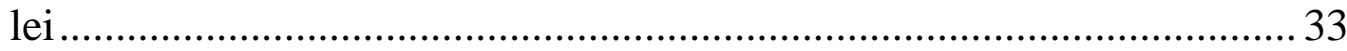

V.IV. Da incomunicabilidade dos bens adquiridos durante a separação de fato 39

V.V. Do direito à taxa de ocupação por uso exclusivo de imóvel na separação de fato

VI. DA ATIVIDADE JURISDICIONAL COMO FONTE DO DIREITO: UMA ATIVIDADE INTERPRETATIVA E CRIATIVA …………............ 45

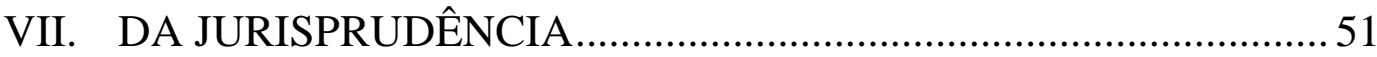

VIII. CONSIDERAÇÕES FINAIS ............................................................ 56

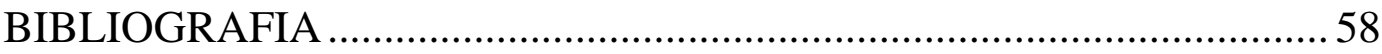




\section{ABREVIATURAS E SÍMBOLOS}

\begin{tabular}{ll} 
abr. & Abril \\
ago. & Agosto \\
A.C. & Apelação Cível \\
Ag. Inst. & Agravo de Instrumento \\
Ag. Reg. & Agravo Regimental \\
art. & Artigo \\
cap. & Capítulo \\
CC & Código Civil \\
dez. & Dezembro \\
DF & Distrito Federal \\
ed. & Editora \\
EDcl. & Embargos Declaratórios \\
fev. & Fevereiro \\
Ibid. & Ibidem ('mesmo autor e mesma obra') \\
IBGE & Instituto Brasileiro de Geografia e Estatística \\
jan. & Janeiro \\
jul. & Julho \\
mai. & Maio \\
mar. & Março \\
Min. & Ministro \\
MS & Mandado de Segurança \\
nov. & Novembro \\
no & Número \\
out. & Outubro \\
p. & Página \\
REsp & Recurso Especial \\
RE & Recurso Extraordinário \\
Rec. Ord. & Recurso Ordinário \\
Rel. & Relator(a) \\
set. & Setembro \\
STF & Supremo Tribunal Federal \\
STJ & Superior Tribunal de Justiça \\
TJ/DF & Tribunal de Justiça do Distrito Federal \\
TJ/RJ & Tribunal de Justiça do Rio de Janeiro \\
TJ/RS & Tribunal de Justiça do Rio Grande do Sul \\
TJ/SC & Tribunal de Justiça de Santa Catarina \\
TJ/SP & Tribunal de Justiça de São Paulo \\
v. & Volume \\
§ & Parágrafo \\
\hline &
\end{tabular}




\section{INTRODUÇÃO}

A legislação civil brasileira é clara ao prever que apenas a separação judicial e o divórcio, a despeito da morte e da invalidade do casamento, é que põem termo aos deveres do matrimônio e ao regime de bens.

Nenhuma disposição legal existe, contudo, sobre o que ocorre com o regime de bens durante o estado existente entre os cônjuges no período precedente à separação judicial e ao divórcio, momento este conhecido por nossas cortes como "separação de fato".

Tal indiferença legislativa se verifica no ordenamento jurídico pátrio, em que pese o reconhecimento doutrinário e jurisprudencial de que diversos efeitos jurídicos inegavelmente decorrem da separação de fato.

Verdade é que essa lacuna da lei expõe o Poder Judiciário ao enfrentamento de casos concretos que, para serem solucionados de forma substancialmente justa, reclamam, não a aplicação fria e literal da lei, mas uma interpretação sistemática e teleológica do Direito, sob pena de se promover uma judicialização do princípio que veda o enriquecimento sem causa.

Comungando dessa constatação, Guilherme Calmon Nogueira da Gama já afirmou:

Há, ainda, de levar em conta a importância da presença de valores éticos e de justiça social no reconhecimento da separação de fato na atualidade, inclusive com o recurso ao princípio que veda o enriquecimento sem causa no que tange às situações jurídicas patrimoniais dos cônjuges no período de rompimento fático da família que anteriormente ambos mantinham. ${ }^{1}$

\footnotetext{
${ }^{1}$ GAMA, Guilherme Calmon Nogueira da. Separação de Fato e Ética no Direito de Família: Revista da Faculdade de Direito da UERJ. Curitiba, v. 13/14, 2005/2006. p. 20.
} 
Bem assim, a questão da taxa de ocupação por uso exclusivo de imóvel na constância da separação de fato é uma das hipóteses em que a ausência de previsão legal específica sobre o regime de bens durante a ruptura fática da conjugalidade pode gerar situações de grave injustiça, à vista do locupletamento indevido do cônjuge que permanece habitando de forma exclusiva o imóvel que antes funcionava como o domicílio do casal, sem, contudo, reparar o outro consorte, que foi impedido de exercer plenamente o seu direito de propriedade sobre o mesmo bem.

O presente trabalho se propõe, portanto, a analisar a problemática brevemente acima exposta, à luz da jurisprudência e da doutrina, a fim de prestar uma contribuição ao vibrante estudo da separação de fato que, embora sempre tenha despertado o interesse da comunidade jurídica, engloba questões sobre as quais a doutrina ainda não se posicionou suficientemente a respeito, a exemplo da específica questão da taxa de ocupação por uso exclusivo de imóvel na constância da separação de fato. 


\section{EVOLUÇÃO LEGISLATIVA DA DISSOLUBILIDADE DO CASAMENTO}

Como apontado, a figura jurídica da separação de fato carece de tratamento legal adequado no ordenamento jurídico pátrio. Vê-se descabida, no entanto, a possível alegação de que tal lacuna de lei encontra justificativa no descompasso do Direito em relação à nova realidade fática, haja vista ser a separação de fato instituto de longa data, conforme demonstra o apanhado histórico da sociedade brasileira.

Assim, a permitir uma melhor compreensão do instituto da separação de fato e de seus desdobramentos com relação à taxa de ocupação por uso exclusivo de imóvel - sobre os quais este trabalho se propôs a debruçar-se necessária uma breve exposição acerca da dinâmica legislativa do casamento e de seu caráter dissolúvel no país.

De início, uma análise da história normativa sobre o matrimônio no Brasil permite constatar uma lenta evolução do instituto, notadamente marcada de muita polêmica, sobretudo no que toca à sua dissolubilidade, dada a íntima ligação do tema com a religião e seus dogmas.

Sobre isso, Sílvio Venosa já afirmou que "a história do divórcio no Brasil traduz uma árdua e calorosa batalha legislativa e social, decorrente de longa e histórica tradição antidivorcista, sustentada basicamente pela Igreja, que erige o casamento em sacramento". ${ }^{2}$

De fato, a instituição do casamento, nos idos do Império, foi regida, basicamente, pelas normas da Igreja Católica, dado que o catolicismo era a religião oficial de nossa metrópole e haja vista que o Estado, nessa época,

\footnotetext{
${ }^{2}$ VENOSA, Sílvio de Salvo. Direito Civil: Direito de família. $7^{\mathrm{a}}$. ed.. São Paulo: Atlas, 2007. p. 187.
} 
não era laico. Dessa forma, os princípios do Direito Canônico representavam a fonte do direito positivo brasileiro, com a aplicação das disposições estabelecidas no Concílio de Trento, formulado entre 1545 e 1553.

Acerca dessa ingerência eclesiástica sobre o casamento no Brasil, Yussef Said Cahali ${ }^{3}$ comenta:

A princípio, a ação da Igreja visou apenas a moralização do casamento do ponto de vista religioso. Porém, à medida que se foi desenvolvendo o direito canônico e, sobretudo, à medida que aumentava o poder espiritual e político da Santa Sé, começou a atribuir-se competência legislativa e jurisdicional. As primeiras medidas datam do século IX. Paulatinamente foi aumentando a sua ingerência até que finalmente o Concílio de Trento (1563) afirmou definitivamente sua competência.

Nesse período, sob a égide do Concílio de Trento, considerava-se o matrimônio como um sacramento de caráter de indissolúvel e com feição claramente patrimonialista. Não é por menos que se admitia aos cônjuges, tão somente, a separação pessoal (divortium quoad thorum et cohabitationem), sendo certo que esta não rompia o vínculo entre o casal, a proteger a incolumidade do patrimônio.

\section{Confirma o exposto, Caio Mário da Silva Pereira:}

Mas, somente com o Concílio de Trento (1545 a 1553), a doutrina da Igreja se consolidou, repelindo-o (o divórcio) em definitivo, e proclamando que o matrimônio é um sacramento com caráter de indissolubilidade. O que se permite em face da Igreja Católica é a separação de corpos, denominada divortium quoad thorum et habitationem, que deixa intacto o vínculo matrimonial. ${ }^{4}$

\footnotetext{
${ }^{3}$ CAHALI, Yussef Said, Enciclopédia Saraiva do Direito, v. 13, p. 455/460 apud BRANDÃO, Vanessa Caús. Do Casamento Religioso com Efeitos Civis e o Novo Código Civil. Disponível em: <http://jus.uol.com.br/revista/texto/2662/do-casamento-religioso-com-efeitos-civis-e-o-novocodigo-civil/1>. Acesso em 10 mai. 2011.

${ }^{4}$ PEREIRA, Caio Mário da Silva. Instituições de Direito Civil, $18^{\mathrm{a}}$ ed.. Rio de janeiro: Forense, 2009. v. 5. p. 281.
} 
Mesmo com o advento da Monarquia, quando o Brasil se tornou independente de Portugal, a normatização eclesiástica do matrimônio permaneceu, na medida em que, através de Decreto, editado em 03 de novembro de 1827, confirmou-se a regência do Concílio de Trento e da Constituição do Arcebispado da Bahia a tudo o que estivesse relacionado ao casamento no país.

Somente com a adoção da forma de governo republicana é que o Brasil se tornou um Estado laico, nos termos do Decreto no 119-A, de 07 de janeiro de $1890^{5}$. No mesmo ano, em 24 de janeiro, foi promulgado o Decreto $\mathrm{n}^{\circ} 181$, que definitivamente instituiu o casamento civil, passando este a ser considerado o único ato válido para a celebração de casamentos no país. Houve, portanto, a secularização do matrimônio.

Com o surgimento dessa nova legislação, passou a existir também a separação de corpos, que, na acepção canônica, foi denominada de "divórcio" (divortium quoad thorum et mensam), em contraposição ao antes existente divortium quoad thorum et habitationem, regido apenas pelas leis da Igreja.

Posteriormente, o advento do Código Civil de 1916 trouxe para o Direito Brasileiro a figura do desquite, que, nas palavras de Pontes de Miranda, nada mais era do que "a separação sem quebra do vínculo" ${ }^{6}$.

Clóvis Beviláqua, autor do projeto do Código Civil em comento, definiu o instituto do desquite como sendo aquele que "põe termo à vida

\footnotetext{
5 “'Art. $1^{\circ}$ E' prohibido á autoridade federal, assim como á dos Estados federados, expedir leis, regulamentos, ou actos administrativos, estabelecendo alguma religião, ou vedando-a, e crear differenças entre os habitantes do paiz, ou nos serviços sustentados á custa do orçamento, por motivo de crenças, ou opiniões philosophicas ou religiosas."

${ }^{6}$ MIRANDA, Pontes de. Tratado de direito privado. Rio de Janeiro: Borsoi, 1955, v.8, p. 36 apud ARAUJO, Eduardo Pereira de. Evolução histórica dos institutos da separação e do divórcio no direito brasileiro e a Emenda Constitucional $n .^{\circ}$ 66/2010. Disponível em <http://www.conteudojuridico.com.br/?artigos\&ver=2.29383\#_edn5>. Acesso em 12 mar. 2011.
} 
comum, separa os cônjuges, restitui-lhes a liberdade, permite-lhes dirigirse, como entenderem, na vida, sem que dependa um do outro, no que quer que seja; mas conserva íntegro o vínculo do matrimônio." 7

A respeito dessa "inovação" legislativa, Sílvio Rodrigues constatou:

A palavra 'desquite' foi introduzida no direito brasileiro com o Código Civil de 1916. O Decreto n. 181/1890, que instituiu entre nós o casamento civil, ainda utilizava a expressão divórcio, embora não o admitisse com o efeito de romper o vínculo conjugal. De forma que o Código Civil, fora modificações menores, nada inovou ao direito anterior, a não ser o nome do instituto. ${ }^{8}$

Em sua constatação, prosseguiu o autor:

Foi oportuna, na ocasião, a introdução do vocábulo "desquite", na lei brasileira. Servia para distinguir a separação judicial de corpos e de bens, única admitida no direito brasileiro de então, do instituto do divórcio com dissolução do vínculo conjugal e possibilidade de novo matrimônio aos divorciados, permitido, na época, em quase todos os países do mundo, mas não admitido entre nós. ${ }^{9}$

Como observado pelo supracitado autor, vale destacar que o desquite fora previsto no art. 315 do Código Civil de 1916 como uma das causas terminativas da sociedade conjugal. Ou seja, colocava fim ao casamento, embora não rompesse o vínculo existente entre o homem e a mulher, impedindo que contraíssem novas núpcias.

$\mathrm{Na}$ estrutura do Código Civil de 1916, portanto, o casamento permanecia indissolúvel; apenas a morte e a invalidação do casamento possibilitavam a quebra do vínculo matrimonial.

\footnotetext{
${ }^{7}$ BEVILÁQUA, Clóvis. Código civil dos Estados Unidos do Brasil comentado por Clóvis Beviláqua. 12 $2^{\mathrm{a}}$ ed.. Rio de Janeiro: Editora Paulo de Azevedo Ltda, 1960, v. 2, p. 208 apud ARAUJO, Eduardo Pereira de. Evolução histórica dos institutos da separação e do divórcio no direito brasileiro e a Emenda Constitucional $n .^{\circ}$ 66/2010. Disponível em <http://www.conteudojuridico.com.br/?artigos\&ver=2.29383\#_edn5>. Acesso em 12 mar. 2011.

${ }^{8}$ RODRIGUES, Sílvio. Direito Civil: Direito de Família. 28ª . ed. São Paulo: Saraiva, 2004, v. 6. p. 213.

${ }^{9}$ Ibid. p. 213.
} 
A despeito desse quadro legislativo, as pessoas não deixavam de, no plano fático, porem fim aos seus relacionamentos. Os cônjuges que não mais pretendiam viver na esfera familiar ao lado de seu consorte, ao invés de se desquitarem, preferiam somente separar-se de fato, na medida em que os efeitos desta separação, de maneira geral, correspondiam aos do desquite. Ademais, a separação de fato era uma situação mais discreta e não gerava despesas, como a obrigação do pagamento de custas e honorários advocatícios com os quais arcavam os desquitados.

Importa destacar que, diante do crescimento do movimento divorcista na sociedade brasileira, que, aos poucos, ganhava força no Congresso (vide os inúmeros projetos de lei que tentaram emplacar o divórcio no país), o legislador constitucional, a fim de evitar uma possível regulamentação infraconstitucional da separação e do divórcio, inseriu a indissolubilidade do casamento na Constituição de 1934.

Nesse tocante, Yussef Said Cahali $^{10}$, em sua obra Separação $e$ Divórcio, fez observação pertinente:

\footnotetext{
Enquanto os demais países que não admitem o divórcio a vínculo consideram a matéria no âmbito do direito civil, o Brasil, em posição singular, havia erigido, a partir da Constituição de 1934 (art. 144), a indissolubilidade do vínculo à condição de preceito constitucional.
}

Não obstante o número de defensores da dissolubilidade do casamento estivesse crescendo exponencialmente, as Constituições de 1937, de 1946 e de 1967 mantiveram-se fiéis à indissolubilidade do vínculo matrimonial, em seus respectivos artigos 124,163 e $175, \S 1^{\circ}$.

Após anos de intensos debates houve a promulgação da Emenda Constitucional $\mathrm{n}^{\circ}$ 9, em 28 de junho de 1977, que alterou o $\S 1^{\circ}$ do art. 175

\footnotetext{
${ }^{10}$ CAHALI, Yussef Said. Divórcio e separação, $10^{\mathrm{a}}$ ed.. São Paulo: Editora Revista dos Tribunais, 2002. p. 41.
} 
da Constituição de 1967, tornando finalmente possível a dissolubilidade do casamento. $\mathrm{O}$ referido dispositivo constitucional passou a vigorar com nova redação:

Art. 175. A família é constituída pelo casamento e terá direito à proteção dos Poderes Públicos.

$\S 1^{\circ}$ - O casamento somente poderá ser dissolvido, nos casos expressos em lei, desde que haja prévia separação judicial por mais de três anos;

A regulamentação desse novo texto constitucional veio com a Lei $n^{0}$ 6.515, de 26 de dezembro de 1977, conhecida como "Lei do Divórcio". O diploma legal revogou os arts. 315 a 328 do Código Civil de 1916, inserindo, definitivamente, o divórcio no ordenamento jurídico brasileiro. Além disso, passou a chamar de "separação judicial" o instituto até então conhecido como "desquite".

Como acertadamente percebeu Nelson Rosenvald ${ }^{11}$, "por questões de política legislativa, o divórcio, naquele momento, foi admitido de maneira extremamente tímida." Isso porque havia a restrição de apenas um divórcio por requerimento da pessoa interessada, a teor do que dispunha o art. $38 \mathrm{da}$ Lei do Divórcio, e desde que precedido de longo prazo de cinco anos de separação de fato ou de três anos de separação judicial.

Decerto que essa limitação do requerimento de divórcio incentivou a manutenção significativa da separação de fato na sociedade. Aqueles que já haviam se divorciado uma vez, por exemplo, apenas separavam-se de fato e seguiam suas vidas, mesmo com nova família.

Seguindo-se a ordem cronológica, adveio a Constituição de 1988, que encampou a facilitação da dissolução do casamento, ao diminuir o lapso temporal para o divórcio por conversão, que passou a ter de ser

\footnotetext{
${ }^{11}$ FARIAS, Cristiano Chaves de; ROSENVALD, Nelson. Direito das Famílias. $2^{\mathrm{a}}$ ed.. Rio de Janeiro: Lumen Juris, 2010. p. 318.
} 
precedido por uma separação judicial de um ano, e ao criar a possibilidade do divórcio direto, hipótese em que era exigida separação de fato por mais de 2 anos.

Com efeito, o art. 226, $\$ 6^{\circ}$ da Constituição Federal de 1988, em sua redação original, previu que:

Art. 226. A família, base da sociedade, tem especial proteção do Estado.

(...)

$\S 6^{\circ}$ - o casamento civil pode ser dissolvido pelo divórcio após prévia separação judicial por mais de um ano nos casos expressos em lei, ou comprovada separação de fato por mais de dois anos.

Merece atenção o reconhecimento da existência da separação de fato por nosso ordenamento jurídico e, mais ainda, de ter ela adquirido status constitucional como causa de dissolução do casamento.

Sistematicamente, a Lei $\mathrm{n}^{\mathrm{o}} 7.841$, de 17 de outubro de 1989, cuidou da adaptação da Lei $n^{\circ} \quad 6.515 / 77$ quanto ao critério temporal constitucionalmente exigido para a conversão do divórcio e para o divórcio direto em si. Nos moldes da nova linha constitucional, essa adaptação incluiu, ainda, a revogação do art. 38, abolindo de vez o limite quantitativo para a concessão de divórcio.

No ensejo, surgiu, em 2002, o novo Código Civil, que, em consonância com o sistema de dissolução matrimonial insculpido na Constituição Federal de 1988, regulamentou a matéria, inovando apenas ao exigir, para a conversão da separação em divórcio, o prazo de um ano a partir do trânsito em julgado da sentença que decreta a separação judicial ou da decisão concessiva da medida cautelar de separação de $\operatorname{corpos}^{12}$.

\footnotetext{
12 “Art. 1.580. Decorrido um ano do trânsito em julgado da sentença que houver decretado a separação judicial, ou da decisão concessiva da medida cautelar de separação de corpos, qualquer das partes poderá requerer sua conversão em divórcio."
} 
Nessa esteira, a Lei n ${ }^{\circ} 11.441$, de 04 de janeiro de 2007, foi editada, sobretudo, para inaugurar as figuras da separação e do divórcio extrajudiciais no Brasil, possíveis, segundo a referida lei, desde que a extinção do vínculo fosse feita de maneira consensual e com o preenchimento de certos requisitos por ela previstos.

Em meio a esse contexto de incentivo à desburocratização do fim do vínculo matrimonial, adveio a Emenda Constitucional no 66, de 13 de julho de 2010 - última alteração legislativa sobre a matéria até o presente momento -, que, ao alterar a redação original do $\$ 6^{\circ}$ do art. 226 da Constituição Federal, tornou o divórcio livre do requisito temporal antes existente.

Apesar de todo esse movimento de facilitação do divórcio e embora não seja mais exigida a separação de fato como um requisito para o divórcio, não se pode pensar que será o fim de tal figura jurídica, pois não são poucos os casais que, pelas mais variadas razões, evitam, protelam ou mesmo esperam a intervenção dos tribunais para darem fim aos seus casamentos.

A inegável presença da separação de fato em nossa sociedade faz do estudo deste instituto verdadeira incumbência aos operadores do Direito, especialmente por não ter sido suficientemente tratada pela lei, sendo certo que muitos dos efeitos jurídicos que provoca dão margem a discussões e a conflitos no plano fático e real, como é o caso da aplicação da taxa de ocupação por uso exclusivo de imóvel. 


\section{CONCEITO JURÍDICO DA SEPARAÇÃO DE FATO}

Diante da constatação de que a ruptura fática do matrimônio é uma realidade na sociedade brasileira, e sem haver noção jurídica positivada na lei acerca do instituto, a doutrina assumiu o papel de conceituá-lo.

Para Teresa Arruda Alvim Wambier"13, a separação de fato é "a situação resultante da quebra da coabitação, praticada por um dos cônjuges, ou por ambos, à revelia de intervenção judicial, e em caráter irreversível."

Orlando Gomes ${ }^{14}$, por sua vez, entende-a como "a cessação da vida em comum dos cônjuges sem intervenção do juiz".

Merece referência, ainda, a concepção de Cesare Massimo Bianca ${ }^{15}$, que entende ser ela "um fato jurídico eficaz, caracterizado pela interrupção efetiva e estável da convivência conjugal não declarada judicialmente."

Em que pesem as variadas conceituações trazidas pela doutrina, importa saber que a definição da separação de fato já foi formulada pelo Supremo Tribunal Federal ${ }^{16}$, quando do julgamento do RE $n^{\circ} 77.24$, em 1976, ocasião em que foi considerada como "o estado existente entres os cônjuges caracterizado pela suspensão, por ato ou iniciativa de um ou de ambos os cônjuges, do relacionamento sexual ou coabitação entre eles, sem qualquer provimento judicial."

\footnotetext{
${ }^{13}$ WAMBIER, Teresa Arruda Alvim. Repertório de Jurisprudência e Doutrina Sobre Direito de Família: Aspectos Constitucionais, Civis e Processuais. São Paulo: Editora Revista dos Tribunais, 1995, v. 2. p. 208-209 apud LIMA, Maria Aparecida Singh Bezerra de. A Separação de Fato entre os Cônjuges e os seus Efeitos. Disponível em: www.cesumar.br/pesquisa/periodicos/index.php/.../article/.../349. Acesso em 25 abr. 2011.

${ }^{14}$ GOMES, Orlando, Direito de Família. $5^{a}$ ed.. Rio de Janeiro: Forense, 1983. p. 284.

${ }^{15}$ BIANCA, Cesare Massimo. Diritto Civile - La Famiglia, Le Successioni, $3^{\mathrm{a}}$ ed.. Milano:Giuffrè Editore, 2001, v. 3, p. 266 apud NADER, Paulo. Curso de Direito Civil: Direito de Família. $2^{\mathrm{a}}$ ed. Rio de Janeiro: Forense, 2008. v. 5. p. 199.

${ }^{16}$ STF, RE no 77204, Rel. Ministro Leitão de Abreu, Brasília, 26 mar. 1976.
} 
Ao lado do delineamento do instituto, a doutrina cuidou de apontar seus requisitos caracterizadores, decerto que não é qualquer rompimento da vida conjugal, refletido na falta de coabitação, que pode ser reconhecido como uma separação de fato, a exemplo da prisão ou da viagem de trabalho de um dos cônjuges.

A esse respeito, o art. 1.569 do Código Civil de 2002 é expresso em admitir, em caráter excepcional, que um dos cônjuges possa se ausentar do domicílio conjugal para atender a encargos públicos, ao exercício da profissão ou a interesses privados relevantes.

Dessa forma, considera-se uma situação como separação de fato quando presentes e conjugados dois elementos: um de caráter objetivo, qual seja, o término da convivência entre os consortes, e outro de cunho subjetivo, que é a intenção voluntária e definitiva de extinção da vida em comum.

Somado a isso, é inegável que o lapso temporal significativo de uma separação de fato contribui para revelar a sua configuração, uma vez que reforça a vontade do casal de por fim à relação.

Em tempo, cumpre registrar que a separação de fato pressupõe um casamento existente e válido, conquanto seja possível vislumbrá-la na hipótese de casamento nulo ou anulável, no período anterior à sentença de nulidade ou anulação, desde que finda a coabitação e presente o animus de separação. 


\section{SEPARAÇÃO DE FATO: UMA REALIDADE À MARGEM DO DIREITO}

Não há dúvidas de que a separação de fato é uma realidade na sociedade brasileira. A título de informação, a pesquisa de registro civil realizada pelo $\mathrm{IBGE}^{17}$ nos anos de 2006 e 2007, de forma indireta e relativa, aponta que naquele biênio, pelo menos, meio milhão de brasileiros formavam o universo dos separados de fato.

Apesar disso, ainda que mencionada em alguns dispositivos legais, a separação de fato não foi regulamentada por nosso ordenamento jurídico vigente. Há que se ter em mente, contudo, que a ausência de lei não significa a inexistência de direito merecedor de tutela, como é o caso, mesmo porque, repise-se, a separação de fato está presente na vida hodierna e na realidade brasileira.

Nesse ponto, encontra lugar a tese da sociologia jurídica de Jean Carbonnier, citada por Carmen Lúcia Silveira Ramos ${ }^{18}$, segundo o qual o Direito não preenche toda a atmosfera humana, havendo, nas sociedades, vazios de direito, razão pela qual situa, ao lado do "Direito", o "não Direito".

A partir disso, o autor formulou dois teoremas fundamentais: (i) o Direito é maior que as fontes formais do Direito; (ii) o Direito é menor que o conjunto das relações entre os homens, o que retoma a idéia do não Direito.

\footnotetext{
${ }^{17}$ IBGE, Estatísticas do Registro Civil, 2006 e 2007 apud RITO, Fernanda Paes Leme Peyneau. Efeitos Patrimoniais da Separação de Fato. Disponível em: <http://www.ibdfam.org.br/?artigos\&artigo=586>. Acesso em 14 abr. 2011.

${ }^{18}$ CARBONNIER, Jean. Flexible droit: pour une sociologie du droit sans rigueur. $7^{\mathrm{a}}$ ed.. Paris: LGDJ, p. 17-18 apud RAMOS, Carmen Lucia Silveira. Família sem Casamento: De Relação Existencial de Fato a Realidade Jurídica. Rio de Janeiro: Renovar, 2000. p. 14
} 
Analisando a doutrina citada, Carmen Lúcia Silveira Ramos ${ }^{19}$ conclui: "O não Direito é a ausência de regulamentação jurídica em um determinado número de relações humanas, nas quais o Direito teria vocação teórica pra estar presente". É onde se situa a separação de fato.

Importa perceber, segundo a mesma autora ${ }^{20}$, que "o não Direito não se confunde, todavia, com o ilícito, ou com o Direito injusto, por estarem estes, a revés, contidos no sistema jurídico".

Ainda de acordo com a supracitada doutrinadora ${ }^{21}$ :

No plano jurídico, o diálogo entre estas esferas do direito e do não direito toma como paradigma o reconhecimento da existência de um direito de origem não estatal, manifestado no cotidiano social, cujas normas e regras de conduta não foram previstas ou incluídas no ordenamento jurídico, que neste sentido flexibiliza seu perfil rígido, como tal anteriormente exclusivo e excludente, entrando em contato com a realidade social.

Desenvolvendo também o tema, aponta Vicenzo Franceschelli ${ }^{22}$ :

As relações de fato se colocam, na sua história, num primeiro momento, como situações irrelevantes para o direito, quando não combatidas pelo ordenamento jurídico. A certa altura, a relação não jurídica é recepcionada pelo sistema, através de um ato de regulação normativa. Transforma-se em situação de direito.

Tal constatação se relaciona com a clássica Teoria Tridimensional do Direito de Miguel Reale ${ }^{23}$, para quem toda experiência jurídica pressupõe sempre três elementos: fato, valor e norma, ou seja, "um elemento de fato, ordenado valorativamente em um processo normativo".

\footnotetext{
${ }^{19}$ RAMOS, Carmen Lucia Silveira. Família sem Casamento: De Relação Existencial de Fato a Realidade Jurídica. Rio de Janeiro: Renovar, 2000. p. 14.

${ }^{20}$ Ibid. p. 14.

${ }^{21}$ Ibid. p. 15 .

22 FRANCESCHELLI, Vincenzo. I rapporti di fatti: ricostruzione della fattispecie e teoria generale. Milano: Giuffrè, 1984, p.11 apud RAMOS, Carmen Lucia Silveira, Família sem Casamento: De Relação Existencial de Fato a Realidade Jurídica. p. 23.

${ }^{23}$ REALE, Miguel apud NADER, Paulo. Introdução ao Estudo do Direito. $26^{\text {a }}$ ed.. Rio de Janeiro: Forense, 2006. p. 390.
} 
De fato, o Direito é impensável sem um substrato de valores. Ele costuma ser analisado como norma, por se tratar da parte mais visível e tangível, principalmente para efeitos práticos, mas nem por isso perde seu contato com a realidade social e o contexto histórico em que se situa.

Conforme constata Reale ${ }^{24}$, o Direito é fruto da experiência e se localiza no mundo da cultura, fenômeno social que é. É uma construção humana, e observa a seguinte lógica: "um valor - podendo ser mais de um incide sobre um prisma (área dos fatos sociais) e se refrata em um leque de normas possíveis, competindo ao poder estatal escolher apenas uma, capaz de alcançar os fins procurados".

Arrematando esse entendimento, manifestou-se José Afonso da Silva ${ }^{25}$ de maneira lapidar: "Não se pode separar fato de Direito, pois este é, como vimos, objeto tridimensional, porque integrado de fato, valor e norma".

Nesse sentido, como bem observou Paulo $\mathrm{Nader}^{26}$, "revela-se que Direito e sociedade são entidades congênitas e que se pressupõem. A sociedade, ao mesmo tempo, é fonte criadora e área de ação do Direito, seu foco de convergência. Existindo em função da sociedade, o Direito deve ser estabelecido à sua imagem, conforme suas peculiaridades, refletindo os fatos sociais, que, no entender de Émile Durkheim, são 'maneiras de agir, de pensar e de sentir, exteriores ao indivíduo, dotadas de um poder de coerção em virtude do qual se lhe impõem"”.

\footnotetext{
${ }_{25}^{24}$ REALE, Miguel, apud NADER, Paulo. Introdução ao Estudo do Direito. p. 391.

${ }^{25}$ SILVA, José Afonso da, Do recurso extraordinário no Direito Processual Brasileiro. p. 125 apud COSTA, Henrique Araújo. Reexame de Prova em Recurso Especial: A Súmula 7 do STJ, cap. 15. Disponível em: <http://www.arcos.org.br/livros/reexame-de-prova-em-recurso-especial-asumula-7-do-stj/capitulo-i-fato-e-direito/2-teorias-de-diferenciacao-entre-fato-e-direito/b-etapadogmatica/b-impossibilidade-de-separacao-entre-fato-e-direito>. Acesso em 24 abr. 2011.

${ }^{26}$ NADER, Paulo. Introdução ao Estudo do Direito. p. 28.
} 
Dada esse atrelamento entre Direito e a sociedade sobre a qual incide, não é à toa a preocupação de que ele se amolde às evoluções sociais, atualizando-se constantemente, em prol de sua finalidade de promoção do bem comum e da justiça.

Pontes de Miranda já dizia que "o mundo jurídico não é mais do que o mundo dos fatos jurídicos, isto é, daqueles suportes fáticos que logram entrar no mundo jurídico". ${ }^{27}$

Na mesma linha, afirmou Vicenzo Franceschelli:

(..) entre fato e direito existe uma contínua relação de osmose, tanto no sentido do fato que se torna juridicamente relevante, quanto no caminho inverso, o que ocorre quando a relação de direito se torna irrelevante, geralmente por cair em desuso, ou vir a ser proibida. ${ }^{28}$

Nessa medida, embora o sistema jurídico vigente possa conferir juridicidade a certas situações configuradas no meio social, convertendo-as em relações jurídicas, é certo que novas situações de fato vão se caracterizando com o correr do tempo, resultantes do contexto e das necessidades de um tempo recente, ficando, assim, à margem do Direito, como ocorre com a separação de fato, com a economia informal, a sociedade de fato, dentre tantos.

Daí porque, com o olhar voltado para o Direito de família - que importa a este trabalho -, Sérgio Gischkow Pereira assevera que "o regramento jurídico da família não pode insistir, em perniciosa teimosia, no obsessivo ignorar das profundas modificações culturais e científicas,

\footnotetext{
${ }^{27}$ MIRANDA, Pontes de, Tratado de Direito Privado. $2^{\mathrm{a}}$. ed.. Rio de Janeiro: Borsoi, 1954. v. 2. p. 183 apud RAMOS, Carmen Lucia Silveira. Família sem Casamento: De Relação Existencial de Fato a Realidade Jurídica. p. 23.

${ }^{28}$ FRANCESCHELLI, Vincenzo. I rapporti di fatti: ricostruzione della fattispecie e teoria generale. Milano: Giuffrè, 1984, p.11 apud Carmen Lucia Silveira. Família sem Casamento: De Relação Existencial de Fato a Realidade Jurídica. p. 23.
} 
petrificado, mumificado e cristalizado em um mundo irreal, ou sofrerá do mal da ineficácia." ${ }^{29}$

Com efeito, no que tange à separação de fato, embora a lei não a tenha previsto como forma de dissolução da sociedade conjugal, nem tenha regulado outro efeito dela decorrente senão o de dar azo à separação ou, anteriormente à $\mathrm{EC} \mathrm{n}^{\circ}$ 66, ao divórcio, o fato social se impõe, em mais um exemplo daquilo que Maria Berenice Dias chama de "revolta dos fatos contra os códigos", trazendo com ele inúmeras situações que colocam à prova a normatização tradicional, acirrando o eterno conflito entre o novo e o velho, obrigando os operadores do Direito a revisar e interpretar alguns institutos.

Dentre os vários exemplos de situações de fato caracterizadas em matéria de família, a separação de fato envolve uma peculiaridade especial, pela circunstância de virtualmente subsistirem as consequiências do casamento e da sociedade conjugal, ao mesmo tempo em que, no mundo real, tal relação não mais subsiste, aparentando configurar uma separação judicial ou divórcio.

Tomando-se como certo que, no que tange à separação de fato, o legislador brasileiro ainda não disciplinou a matéria devidamente, é de se reparar que foi deixado grande espaço para a construção doutrinária e jurisprudencial.

A doutrina cuida do tema, embora dispense maior atenção a efeitos jurídicos diversos daquele objeto do presente trabalho, o que torna ainda mais interessante e desafiador o tema que se pretende discutir.

\footnotetext{
${ }^{29}$ PEREIRA, Sérgio Gischkow. Estudos de direito de família. p. 35. apud DIAS, Maria Berenice. Manual de Direito das Famílias. $7^{\mathrm{a}}$ ed.. São Paulo: Editora Revista dos Tribunais, 2010. p. 29.
} 
A jurisprudência, por sua vez, ainda se vê apegada à interpretação literal da lei a respeito, muitas vezes ignorando os elementos fáticos que reclamam interpretação que afaste o locupletamento indevido no caso concreto. 


\section{DA APLICABILIDADE DA TAXA DE OCUPAÇÃO POR USO EXCLUSIVO DE IMÓVEL NA SEPARAÇÃO DE FATO}

À luz de sua definição, insta perceber que a separação de fato não constitui um estado civil; pelo contrário, representa a coexistência no mais das vezes conturbada do estado civil de casado com a realidade concreta da separação, o que, reconhecidamente, gera inúmeros efeitos jurídicos.

Dentre esses vários efeitos, exalta-se um, de natureza patrimonial, que apresenta incidência por demais corriqueira na vida social, conquanto nunca tenha ganhado especial atenção da doutrina, muito menos da lei. Trata-se da incidência da taxa de ocupação por uso exclusivo de imóvel durante a separação de fato.

Quando um cônjuge separado de fato se utiliza exclusivamente do imóvel de co-propriedade do outro cônjuge, este último se vê privado do exercício de seus direitos de uso e gozo do bem, o que faz exsurgir o seu direito à indenização, que corresponderia à quantia equivalente a $50 \%$ (cinqüenta por cento) do valor do aluguel do imóvel, configurando o que a doutrina chama de "taxa de ocupação por uso exclusivo de imóvel".

A origem desse direito à indenização inegavelmente remonta ao direito de propriedade, e, por esta relação, reclama a observância de uma lógica capaz de evitar o enriquecimento sem causa, expressamente vedado por nosso ordenamento jurídico. 


\section{V.I. Do enriquecimento sem causa}

Dispõe o art. 884 do Código Civil de 2002: "aquele que, sem justa causa, se enriquecer à custa de outrem, será obrigado a restituir o indevidamente auferido, feita a atualização dos valores monetários".

Tal disposição legal repousa na fórmula milenar "nemo potest lucupletari, jactura aliena", ou seja, ninguém pode enriquecer sem causa.

Reputa-se que o enriquecimento carece de causa quando o direito não o aprova ou consente, porque não existe uma relação ou um fato que, de acordo com os princípios do sistema jurídico, justifique o deslocamento patrimonial. $^{30}$

Frise-se ser necessário para a caracterização do enriquecimento sem causa que essa vantagem patrimonial se dê à custa de outrem, como expõe o dispositivo legal supracitado.

A lógica que se apresenta, mesmo não tendo sido sempre positivada, eis que inaugurada apenas no Código Civil de 2002, sempre teve reconhecimento na doutrina e na jurisprudência como um princípio geral do Direito. Existe entendimento, inclusive, de que a proibição ao locupletamento indevido seja garantia constitucional implícita. ${ }^{31}$

A par de toda a sua importância para a promoção da Justiça no caso concreto, inúmeros são os julgados que invocam a preponderância da vedação ao enriquecimento sem causa como embasamento para a solução da lide.

\footnotetext{
${ }^{30}$ TEPEDINO, Gustavo et al. Código Civil Interpretado: Conforme a Constituição da República. Rio de Janeiro: Renovar, 2006. v. 2. p. 755.

${ }^{31}$ STF, Ag. Reg. em Ag. Instr. 182458, Rel. Ministro Marco Aurélio, Brasília. 04 mar. 1997.
} 
Senão vejamos:

PROCESSUAL CIVIL. ADMINISTRATIVO. AGRAVO REGIMENTAL. AGRAVO DE INSTRUMENTO CONVERTIDO EM RECURSO ESPECIAL. VIOLAÇÃO AO ART. 535 DO CPC. INOCORRÊNCIA. DANO MORAL. PRETENSÃO NEGADA NA INSTÂNCIA ORDINÁRIA. DECISÃO TOMADA COM BASE EM APRECIAÇÃO DE FATOS, INSUSCETÍVEL DE SER REEXAMINADA NO ÂMBITO DO RECURSO ESPECIAL. DISSIIDIO JURISPRUDENCIAL. AUSÊNCIA DE COTEJO ANALÍTICO.

I - Não ocorre ofensa ao art. 535 do CPC se o e. Tribunal de origem, sem que haja recusa à apreciação da matéria, embora rejeitando os embargos de declaração, considera não existir defeito a ser sanado. Precedentes.

II - A ressalva no sentido de eventual dedução das parcelas já recebidas no âmbito administrativo não constitui julgamento extra petita, mas apenas homenagem ao princípio que veda o enriquecimento sem causa. Precedentes.

III - As ponderações que levaram o Tribunal $a$ quo a negar a indenização não podem ser reexaminadas no âmbito do recurso especial, que não deve ser tomado à conta de simples recurso de revisão, porquanto possui nobre função, que é assegurar a integridade do direito federal, e só reflexamente tutelar direito

subjetivo da parte. Precedentes.

IV - Para caracterização do dissídio, indispensável que se faça o cotejo analítico entre a decisão reprochada e os paradigmas invocados, ex vi arts. 255 do RISTJ e 541 do CPC. Agravo regimental desprovido. ${ }^{32}$

(Grifos nossos)

ADMINISTRATIVO E ECONÔMICO. CONTRATO ADMINISTRATIVO DE OBRA PÚBLICA. CUMPRIMENTO DA OBRIGAÇÃO VERIFICADO PELA ADMINISTRAÇÃO PÚBLICA, MEDIANTE CRITÉRIO DE MEDIÇÃO. FIXAÇÃO DO TERMO INICIAL DA CORREÇÃO MONETÁRIA. ATRASO NO PAGAMENTO. ILÍCITO CONTRATUAL. DESVALORIZAÇÃO DA MOEDA. INEXISTÊNCIA NO CONTRATO DE CLÁUSULA, PREVENDO A DATA PARA O PAGAMENTO DO PREÇO AVENÇADO. NECESSIDADE DE VERIFICAÇÃO DO CUMPRIMENTO DA OBRIGAÇÃO E O CONSEQÜENTE PREJUÍZO ECONÔMICO PELO ATRASO. OBSERVÂNCIA DO VALOR REAL DO CONTRATO.

1. A mora no pagamento do preço avençado em contrato administrativo, constitui ilícito contratual. Inteligência da Súmula 43 do STJ.

2. A correção monetária, ainda que a lei ou o contrato não a tenham previsto, resulta da integração ao ordenamento do princípio que veda o enriquecimento sem causa e impõe o equilíbrio econômico-financeiro do contrato.

3. O termo inicial para a incidência da correção monetária nos contratos administrativos de obra pública, na hipótese de atraso no pagamento, não constando do contrato regra que estipule a data para o efetivo pagamento do preço avençado, deverá corresponder ao $1^{\circ}$ (primeiro) dia útil do mês subsequiente à realização da obra, apurada pela Administração Pública mediante critério denominado medição. Precedentes do STJ (REsp 71127/SP, REsp 61817/SP).

\footnotetext{
${ }^{32}$ STJ, Ag. Rg. nos Edcl. no Ag. Rg. no Ag. 727485/RJ, Rel. Ministro Felix Fischer, Brasília, 20 nov. 2006.
} 
4. O retardamento em pagar medições de obras já efetuadas configura violação do contrato e a inadimplência de obrigação juridicamente pactuada, com conseqüências que se impõem ao contratante público.

5. Recurso conhecido e provido, para reformar o acórdão, modificando o termo inicial para a incidência da correção monetária para o período de atraso no pagamento. $^{33}$

(Grifos nossos)

CIVIL - AÇÃO ORDINARIA - INDICE DE CORREÇÃO MONETARIA PARA JANEIRO DE 1989 - SISTEMA DE CALCULO REGIDO PELO ART. 9., I E II, DA LEI NR. 7.730/89.

I - A JURISPRUDENCIA DO STJ PACIFICOU ENTENDIMENTO NO SENTIDO DE QUE O IPC DIVULGADO PARA JANEIRO DE 1989 TEM O PERCENTUAL DE 42,72\%, EIS QUE, SEGUNDO AS NORMAS REGENTES, TAL INDICE EFETIVAMENTE REFLETE O NIVEL INFLACIONARIO QUE, NUM PERIODO DE 51 (CINQUENTA E UM) DIAS, ACUMULOU MONTANTE DE 70,28\%. HÃO DE SE CONSIDERAR OS FATOS ECONOMICOS, NA APLICAÇÃO DE TAIS NORMAS, DANDO-SE-LHES, INCLUSIVE, EXEGESE AOS SEUS TERMOS, AMOLDANDO-SE AOS PRINCIPIOS GERAIS DE DIREITO, QUAL SEJA, O QUE VEDA O ENRIQUECIMENTO SEM CAUSA (RESP NR. 43.055-O/SP, JULGADO EM 25.8.94).

II - A TAXA REFERENCIAL NÃO E INDICE ADEQUADO PARA CORRIGIR O VALOR REAL DA MOEDA.

III - RECURSO CONHECIDO E PARCIALMENTE PROVIDO. ${ }^{34}$

(Grifos nossos)

A relevância de tal princípio também aqui se apresenta, na medida em que encerra o especial fundamento para se admitir a aplicação da taxa de ocupação por uso exclusivo de imóvel durante a separação de fato, como pretende sustentar este trabalho.

\footnotetext{
${ }^{33}$ STJ, REsp 679525, Rel. Ministro Luiz Fux, Brasília, 12 mai. 2005.

${ }^{34}$ STJ, REsp. 64.352, Rel. Ministro Waldemar Zveiter, Brasília, 26 set. 1995.
} 


\section{V.II. Mancomunhão e condomínio: dois institutos jurídicos distintos}

Vislumbra-se a seguinte hipotética e corriqueira situação: o cônjuge que, por alguma circunstância determinante, deixa seu lar, findando a convivência com seu ex-consorte - pois que cessado o afeto e a comunhão de interesses -, vê-se sem destino, tendo, no mais das vezes, que se hospedar em hotéis ou na casa de amigos e parentes, enquanto que o imóvel para cuja aquisição colaborou encontra-se ocupado unicamente por seu excônjuge, sem qualquer contrapartida por esse uso exclusivo.

Não é preciso ser um estudioso do Direito para saber que essa situação representa um enriquecimento sem causa daquele cônjuge que se utiliza exclusivamente do imóvel de co-propriedade com seu ex-consorte, sem ressarci-lo por isto.

Basta um senso de Justiça para notar que a falta de indenização ao cônjuge que foi privado de seu direito de propriedade de forma indevida e em proveito de outrem é irrazoada e injusta, e, por isso, deve ser tolhida.

E de fato esse locupletamento sem causa é vedado por nosso sistema jurídico, como prevê expressamente o Código Civil de 2002, em seu art. 884 , conforme já mencionado.

A matéria, portanto, não traria maiores questionamentos, não fosse a lei prever que os bens do casal, na constância do matrimônio, assumem estado de mancomunhão, assim permanecendo até o momento da partilha, que apenas pode ocorrer com a separação judicial ou o divórcio. 
É que na mancomunhão, segundo Pontes de Miranda ${ }^{35}$, os bens não pertencem a cada um dos cônjuges em metades ideais: pertencem ao casal. A mancomunhão pode ser entendida, portanto, como a situação jurídica da propriedade dos bens pelo casal, em que não há qualquer distinção, divisão, ou ainda, preferência entre eles.

Implica dizer que não existe direito individual sobre os bens em estado de mancomunhão, o que torna inviável a possibilidade de ressarcimento do cônjuge que foi privado de seu direito de propriedade em razão do uso exclusivo do imóvel pelo ex-consorte.

Como se vê, o direito de propriedade, na circunstância do casamento, encontra contornos próprios, à luz do regramento existente para o regime de bens escolhido pelo casal.

Durante o matrimônio, os bens adquirem o status de mancomunhão conforme o regime de bens estipulado, pois, a depender do tipo adotado, admite-se, ou não, a comunicabilidade total ou parcial dos bens, seja por presunção legal de esforço comum, seja por comprovação da existência deste para a aquisição da coisa.

Não é demais lembrar que os regimes de bens, na concepção de Caio Mário da Silva Pereira ${ }^{36}$, constituem “os princípios jurídicos que disciplinam as relações econômicas entre os cônjuges, na constância do casamento".

Há que se mencionar, ainda, que o Código Civil vigente, apoiado no princípio da livre estipulação de pactos, tipifica quatro espécies de regimes convencionais de bens, quais sejam: regime da comunhão parcial de bens

\footnotetext{
${ }^{35}$ MIRANDA, Pontes de, Tratado de Direito de Família, Campinas: Bookseller, 2001. p. 230 apud TJ/SP, A.C. 2486104800 , Rel. Desembargador Antonio Vilenilson, São Paulo, 02 out. 2007.

${ }^{36}$ PEREIRA, Caio Mário da Silva, Instituições de Direito Civil, v. 5. p. 189.
} 
(arts. 1658 a 1666, CC), regime da comunhão universal de bens (arts. 1887 a 1671, CC), regime da participação final nos aquestos (arts. 1672 a 1686, CC) e regime da separação absoluta (arts. 1687 e 1688, CC).

Assim, ressalvadas as hipóteses excepcionais em que a lei impõe expressamente um regime separatório dos bens (art. 1641, CC), poderão os nubentes, quando da habilitação matrimonial, perante o Cartório do Registro Civil de Pessoas Naturais, livremente, eleger o estatuto patrimonial do casamento, através de um pacto antenupcial. Em caso de silêncio dos nubentes, a lei presume a adoção do regime da comunhão parcial de bens, a teor do que dispõe o art. 1640, CC.

Dentre esses regimes, somente o da separação convencional não admite a comunicabilidade dos bens, nem mesmo, segundo a melhor doutrina, por comprovação de esforço comum para a aquisição do bem, que é admitida para o regime da separação obrigatória de bens, por força de construção jurisprudencial, consagrada pelo Enunciado 377 da Súmula do Supremo Tribunal Federal ${ }^{37}$.

Sendo assim, verificada a comunicabilidade dos bens em razão do casamento, ou seja, verificado o estado de mancomunhão do patrimônio dos cônjuges, importa saber que esse estado irá perdurar até que o vínculo que une o casal se extinga, por ocasião de declaração de uma sentença judicial ou de uma escritura pública, quando, então, passam a ser aplicáveis as regras de condomínio aos bens que forem de co-propriedade do casal.

Nesse passo, importante salientar a distinção entre a mancomunhão e o condomínio, sendo este último configurado, segundo as lições de Caio

\footnotetext{
37 “STF Súmula no 377 - No regime de separação legal de bens, comunicam-se os adquiridos na constância do casamento."
} 
Mário da Silva Pereira ${ }^{38}$, “quando a mesma coisa pertence a mais de uma pessoa, cabendo a cada uma delas igual direito, idealmente, sobre o todo e cada uma de suas partes".

O autor prossegue na sua explanação, afirmando que:

A cada condômino é assegurada uma quota ou fração ideal da coisa, e não uma parcela material desta. Cada cota ou fração não significa que a cada um dos comproprietários se reconhece a plenitude dominial sobre um fragmento físico do bem, mas que todos os comunheiros têm direitos qualitativamente iguais sobre a totalidade dele, limitados contudo na proporção quantitativa em que concorre com os outros comproprietários na titularidade sobre o conjunto.

Maria Berenice Dias ${ }^{39}$ sintetiza as idéias antes expostas:

Depois da separação de fato ou do divórcio, sem a realização da partilha, os bens permanecem em estado de mancomunhão, expressão corrente na doutrina, que, no entanto, não dispõe de previsão legal. De qualquer sorte, quer dizer que os bens pertencem a ambos os cônjuges ou companheiros em 'mão comum'. Tal figura distingue-se do condomínio: situação em que o poder de disposição sobre a coisa está nas mãos de vários sujeitos simultaneamente (CC 1.314 e seguintes).

Essa distinção conceitual possui relevância para o tema, na medida em que a questão sob exame surge, basicamente, da imposição legal do estado de mancomunhão dos bens à situação (separação de fato) que reclama a aplicação das regras de condomínio, a fim de que se evite o enriquecimento sem causa.

\footnotetext{
${ }^{38}$ PEREIRA, Caio Mário da Silva, Instituições de Direito Civil. $20^{\mathrm{a}}$ ed.. Rio de Janeiro: Forense, 2009. v. 4. p. 151-152.

${ }^{39}$ VIANA, Marco Aurélio S.. Da União Estável. p. 27 apud DIAS, Maria Berenice. Manual de Direito das Famílias. p. 322.
} 


\section{V.III. Da necessidade de uma interpretação sistemática e teleológica da lei}

O ponto crucial para se compreender esta discussão está em perceber que a lei civil somente apontou a separação judicial e o divórcio (a despeito da morte e da anulação do casamento) como marcos para o fim do regime de bens e, por conseguinte, do estado de mancomunhão, sem fazer qualquer menção à separação de fato.

Com efeito, o artigo 1576 do novo Código Civil é claro ao dispor que: "A separação judicial põe termo aos deveres de coabitação e fidelidade recíproca e ao regime de bens".

Da mesma forma, a redação do art. 1571 do mesmo diploma legal não deixa dúvidas de que a separação de fato não foi alçada a uma das formas de extinção do vínculo conjugal, sujeitando-se, com isso, ao regime de bens e ao consequente estado de mancomunhão. In verbis:

Art. 1.571. A sociedade conjugal termina:

I - pela morte de um dos cônjuges;

II - pela nulidade ou anulação do casamento;

III - pela separação judicial;

IV - pelo divórcio.

$\S 1^{\circ} \mathrm{O}$ casamento válido só se dissolve pela morte de um dos cônjuges ou pelo divórcio, aplicando-se a presunção estabelecida neste Código quanto ao ausente.

Ocorre, todavia, que o término de um casamento geralmente se dá muito antes da lavratura da escritura ou da prolação da sentença judicial de separação ou de divórcio.

Não há dúvidas que a ruptura fática da relação é que caracteriza, no mundo real, o fim do matrimônio. A partir dela, o casamento se torna 
despido de seu caráter social, deixando de existir independentemente de um provimento judicial que assim o decrete.

\section{Como bem observa Maria Berenice Dias ${ }^{40}$ :}

Quando cessa a convivência, o casamento não gera mais efeitos, faltando apenas a chancela estatal. $\mathrm{O}$ casamento nada mais produz, porque simplesmente deixou de existir. Não há mais sequer o dever de fidelidade, a impedir a constituição de novos vínculos afetivos. Tanto isso é verdade que os separados de fato podem constituir união estável. Só há proibição de casar.

Oportuno lembrar que a finalidade do casamento é, sobretudo, a comunhão de vida e de interesses, como aponta a melhor doutrina ${ }^{41}$, confirmada pela redação do art. 1.511 do Código Civil de $2002^{42}$. Outrossim, há muito o casamento livrou-se de uma feição preponderantemente patrimonialista para ser calcado basicamente no afeto.

\section{Baseando-se nessas premissas, Teresa Arruda Alvim Wambier ${ }^{43}$} pondera:

A ratio essendi das regras relativas à comunhão de bens entre os cônjuges é a existência real e concreta da vida em comum", de modo que "carece de sentido, quer jurídico, quer moral, aplicar-se um regime de comunhão a um 'casal' que nem mais 'casal' é, ou era, por ausência absoluta de affectio maritalis, de identidade de espíritos, vontades, planos, trabalho e bem comum.

Acrescenta, ainda, a autora ${ }^{44}$ que:

A doutrina e a jurisprudência mais atuais têm propendido, embora às vezes de forma não expressa, a estabelecer uma diferenciação nítida entre o casamento que existe formalmente e de fato (= casamento formalizado + vida em comum) e o casamento que não existe, senão formalmente.

\footnotetext{
${ }^{40}$ DIAS, Maria Berenice. Manual de Direito das Famílias. 6ª ed.. p. 297.

${ }^{41}$ cf. FARIAS, Cristiano Chaves de; ROSENVALD, Nelson. Direito das Famílias. p. 113.

42 "Art. 1.511. O casamento estabelece comunhão plena de vida, com base na igualdade de direitos e deveres dos cônjuges."

${ }^{43}$ WAMBIER, Teresa Arruda Alvim. Meação de Patrimônio Adquirido por um dos Cônjuges Durante a Separação de Fato. Revista de Processo nº 70, 1993. p. 170.

${ }^{44}$ Ibid. p. 170.
} 
Para o mesmo caminho estão voltadas as palavras de Segismundo Gontijo $^{45}$, apesar de contextualizadas com o antigo Código Civil de 1916:

\begin{abstract}
$\mathrm{Na}$ verdade o casamento não se perfaz com a mera assinatura de um termo no livro do cartório do registro civil; entre seus elementos constitutivos, definidos no artigo 231 do CC, estão a vida em comum e a mútua assistência. Inexistindo convivência, naturalmente inexistirá constância do casamento com o conseqüente fim da sociedade conjugal e do regime de bens. Uma das consequiências lógicas da separação de fato será a da ausência das condições para o desenvolvimento válido e regular da sociedade conjugal e, até mesmo, do casamento, pois se revelará incompossível o cumprimento dos respectivos deveres fundamentais naquela situação anômala que, por sê-la, deverá ser remediada por uma futura decisão judicial. Essa situação será tudo o que quiser, menos constância da sociedade conjugal.
\end{abstract}

Como bem apontou o autor, a separação de fato representa o fim do vínculo que sustentava o casamento, de vez que, deixando de existir o principal, certo é que os deveres anexos, assim como o regime de bens que nele vigorava também se extinguem.

Maria Berenice Dias ${ }^{46}$ concorda:

O fim da vida em comum leva à cessação do regime de bens, seja ele qual for, porquanto já ausente o ânimo socioafetivo, real motivação da comunicação patrimonial.

A fundamentar esse entendimento de que o fim da vida em comum deve ser o momento de verificação dos bens para efeitos de partilha, a referida autora ${ }^{47}$ ressalta a norma insculpida no art. 1.683 do Código Civil de 2002, segundo a qual: "na dissolução do regime de bens por separação judicial ou por divórcio, verificar-se-á o montante dos aquestos à data em que cessou a convivência".

\footnotetext{
${ }^{45}$ GONTIJO, Segismundo. Do Regime de Bens na Separação de Fato. Revista dos Tribunais no 735 , jan/1997. p. 141.

${ }_{46}^{46}$ DIAS, Maria Berenice. Manual de Direito das Famílias. $6^{\text {a }}$ ed.. p. 298.

${ }^{47}$ DIAS, Maria Berenice. Manual de Direito das Famílias. $7^{\mathrm{a}}$ ed.. p. 295.
} 
Para a doutrinadora, embora tal regra esteja contida no capítulo do Código Civil que cuida do regime da participação final dos aquestos, mereceria ela ser aplicada a qualquer dos regimes de bens, funcionando como regra geral. Trata-se, segundo a doutrina, de norma heterotópica.

\section{Compartilhando a mesma linha de pensamento, Rolf Madaleno ${ }^{48}$} aponta:

Essa massa de bens advindos do casamento reside na união afetiva do casal e na comunidade dos seus esforços dirigidos para um único objetivo, representado pelo crescimento econômico da sua sociedade afetiva. Dissolvido o casamento ou a própria união estável pela perda de sua affectio societatis e não mais coabitando os sócios conjugais, também desaparece o direito de comunidade dos bens, que justamente emerge da comunidade de esforços e interesses, enfim, de uma convivência que nada mais produz porque deixou de existir.

Apegada à mesma idéia, Carmen Lúcia Silveira $\operatorname{Ramos}^{49}$ desenvolve:

A propósito, uma análise sistemática e estritamente técnico-jurídica desta questão tem levado à conclusão de que a separação de fato, não pondo termo à sociedade conjugal, mantém-se íntegro o estatuto patrimonial de base, de sorte a preservarse a comunicabilidade dos bens adquiridos durante a desunião não formalizada do casal.

E prossegue ${ }^{50}$ :

Em sentido contrário, uma análise interdisciplinar leva a preconizar que a separação de fato seja suficiente para ilidir o estipulado no regime de bens do casamento, em nome da justiça do caso concreto e do fato social envolvido.

De fato, não se afigura razoável a manutenção de um regimento de bens, com presunção de esforço comum na formação do patrimônio, quando cessada a convivência e a comunhão de interesses daqueles que uma vez já foram um casal.

\footnotetext{
${ }^{48}$ MADALENO, Rolf. Novas Perspectivas no Direito de Família. Porto Alegre: Livraria do Advogado, 2000. p. 138 apud DIAS, Maria Berenice et al. Direito de Família e o Novo Código Civil, $2^{\mathrm{a}}$ ed.. Belo Horizonte: Del Rey, 2001. p. 168.

${ }^{49}$ RAMOS, Carmen Lucia Silveira. Família sem Casamento: De Relação Existencial de Fato a Realidade Jurídica. p. 153.

${ }^{50}$ Ibid. p. 153.
} 
Tal raciocínio está em perfeita sintonia com o sistema existente no Direito de Família brasileiro, diante da adoção dos mesmos postulados que levaram o Supremo Tribunal Federal a editar a Súmula 377, cujo teor trata da comunhão de aquestos no regime obrigatório de separação de bens, quando a aquisição se verificar em decorrência da comunhão de recursos e esforços dos cônjuges.

Inegável que esse entendimento sumulado construiu-se com base no princípio do não enriquecimento indevido, afastando a interpretação literal da sistemática vigente para o regime obrigatório de bens, tendo em vista que a aplicação fria da lei, nesse caso, é capaz de gerar injustiças no caso concreto.

Outrossim, com a mesma finalidade, o princípio que veda o enriquecimento sem causa deve preponderar quando do enfrentamento da questão da aplicabilidade da taxa de ocupação por uso exclusivo de imóvel na separação de fato.

Desse modo, forçoso concluir que, conquanto os arts. 1575 e 1576 do Código Civil, conjugados com o art. 1571 do mesmo diploma legal, determinem que apenas a sentença judicial ou a escritura pública são capazes de dissolver o casamento, pondo fim ao regime de bens, é a data da separação de fato que se impõe como momento de verificação dos bens para efeito de partilha. É a separação de fato que finaliza, definitivamente, o estado de mancomunhão dos bens, podendo-se aplicar as regras de condomínio aos bens que forem de co-propriedade do casal.

Ignorar essa verdade importa, no mais das vezes, em se deixar que prevaleçam soluções injustas, admitindo-se o enriquecimento indevido de 
um dos cônjuges, o que certamente quis nosso legislador evitar quando fixou a regra constante do já comentado art. 884 do Código Civil vigente.

À vista desse enriquecimento sem causa, como bem apontou Caio Mário da Silva Pereira ${ }^{51}$, em sua clássica obra Instituições de Direito Civil, na separação de fato, a doutrina e a jurisprudência já vêm consagrando a incomunicabilidade dos bens, distinguindo a existência formal do casamento e a constância do casamento, verificada nesta a convivência conjugal e a efetiva comunhão de vida.

${ }^{51}$ PEREIRA, Caio Mário da Silva. Instituições de Direito Civil. v. 5. p. 272. 


\section{V.IV. Da incomunicabilidade dos bens adquiridos durante a separação de fato}

Atenta aos efeitos patrimoniais gerados pela separação de fato, a doutrina brasileira é ampla e firme em defender a incomunicabilidade dos bens adquiridos pelo cônjuge separado de fato, principalmente quando este já se encontra em uma nova relação.

Guilherme Calmon Nogueira da Gama ${ }^{52}$ é um dos que defendem a incomunicabilidade dos bens durante a separação de fato:

Para evitar situações injustas, prevenindo o enriquecimento sem causa (novo CC, art. 884), além de cumprir os valores e princípios constitucionais no que tange à ética solidária das relações intersubjetivas, urge que se considere que não se comunicam, e, por isso, não se sujeitam à partilha, os bens adquiridos durante a separação de fato do casal. A falta de comunhão plena de vida, representando a vertente do referencial ético do casamento, conduz à vedação do aproveitamento por parte dos cônjuges de efeitos pessoais e patrimoniais que somente se produzem diante do atendimento à função social da família. Como na hipótese da separação de fato, inexiste convívio conjugal, naturalmente deverá ser cessado o efeito da comunicação de bens entre os cônjuges.

Deveras, uma vez ocorrido o desfazimento da comunhão de vida, não há porque se presumir o esforço do cônjuge que em nada contribuiu para a aquisição do bem após a separação de fato, afastando qualquer justificativa para seu enriquecimento à custa do outro cônjuge que empregou seus recursos para tal aquisição.

É nesse compasso que os tribunais brasileiros, inclusive o Superior Tribunal de Justiça, já reconhecem a incomunicabilidade de bens durante a separação de fato, como demonstra a ementa abaixo transcrita de acórdão ${ }^{53}$ pertinente ao que se expõe:

\footnotetext{
${ }^{52}$ GAMA, Guilherme Calmon Nogueira da. Separação de Fato e Ética no Direito de Família: Revista da Faculdade de Direito da UERJ . v. 13/14. 2005/2006. p. 29.

${ }^{53}$ STJ, EDcl no Rec. Ord. em MS, Rel. Ministro Fernando Gonçalves, Brasília, 14 dez. 2004.
} 
RMS. EMBARGOS DE DECLARAÇÃO. MATÉRIA CUJO DESLINDE RECLAMA INVESTIGAÇÃO PROBATÓRIA. VEDAÇÃO EM MANDADO DE SEGURANÇA.

1. Em princípio, consoante pacificado entendimento jurisprudencial predominante nos órgãos fracionários, integrantes da Segunda Seção deste Superior Tribunal de Justiça, bens adquiridos após a separação de fato, "à conta de um só dos cônjuges", não se comunicam ao outro consorte (Resp 32218 Resp 40785 e Resp 140694).

2. Afirmando, no entanto, a instância de origem em sentido diverso, ou seja, que os bens, malgrado a separação, permanecem no patrimônio comum, registrados em nome de pessoa jurídica, da qual participa o casal, a matéria envolve investigação probatória, vedada em sede de mandado de segurança.

3. Embargos de declaração rejeitados.

Importa notar que essa nova linha jurisprudencial geralmente encontra fundamento na doutrina de Yussef Said Cahali ${ }^{54}$, de quem se extrai o seguinte brilhante comentário: "se o bem foi adquirido quando nada mais havia em comum entre o casal, repugna ao Direito e à Moral reconhecer comunhão apenas de bens e atribuir a metade desses ao outro cônjuge".

Igualmente serve de substrato para esse novo posicionamento o permissivo legal de constituição de união estável durante a separação de fato, expressamente disposto pelo art. 1.723, § $1^{\mathrm{o}}$ do Código Civil de 2002, in verbis:

Art. 1.723. É reconhecida como entidade familiar a união estável entre o homem e a mulher, configurada na convivência pública, contínua e duradoura e estabelecida com o objetivo de constituição de família.

$\S 1^{\mathrm{o}}$ A união estável não se constituirá se ocorrerem os impedimentos do art. 1.521; não se aplicando a incidência do inciso VI no caso de a pessoa casada se achar separada de fato ou judicialmente.

É que, em uma leitura sistemática desse diploma legal, percebe-se que a manutenção do regime de bens, com a comunicabilidade de todos os bens do casal faticamente separado, quando já existente nova união estável entre um deles e terceiro, importaria na convivência de dois regimes de

\footnotetext{
${ }^{54}$ CAHALI, Yussef Said, Divórcio e Separação. p. 803.
} 
bens de origens distintas, na medida em que o art. 1.725 da lei civil determina a aplicação das regras da comunhão parcial à união estável.

A jurisprudência já está atenta a essa incompatibilidade, conforme se percebe a partir do julgado abaixo colacionado ${ }^{55}$ :

DIREITO CIVIL. FAMÍLIA. SUCESSÃO. COMUNHÃO UNIVERSAL DE BENS. INCLUSÃO DA ESPOSA DE HERDEIRO, NOS AUTOS DE INVENTÁRIO, NA DEFESA DE SUA MEAÇÃO. SUCESSÃO ABERTA QUANDO HAVIA SEPARAÇÃO DE FATO. IMPOSSIBILIDADE DE COMUNICAÇÃO DOS BENS ADQUIRIDOS APÓS A RUPTURA DA VIDA CONJUGAL. RECURSO ESPECIAL PROVIDO.

1. Em regra, o recurso especial originário de decisão interlocutória proferida em inventário não pode ficar retido nos autos, uma vez que o procedimento se encerra sem que haja, propriamente, decisão final de mérito, o que impossibilitaria a reiteração futura das razões recursais.

2. Não faz jus à meação dos bens havidos pelo marido na qualidade de herdeiro do irmão, o cônjuge que encontrava-se separado de fato quando transmitida a herança.

3. Tal fato ocasionaria enriquecimento sem causa, porquanto o patrimônio foi adquirido individualmente, sem qualquer colaboração do cônjuge.

4. A preservação do condomínio patrimonial entre cônjuges após a separação de fato é incompatível com orientação do novo Código Civil, que reconhece a união estável estabelecida nesse período, regulada pelo regime da comunhão parcial de bens (CC 1.725) 5. Assim, em regime de comunhão universal, a comunicação de bens e dívidas deve cessar com a ruptura da vida comum, respeitado o direito de meação do patrimônio adquirido na constância da vida conjugal. 6. Recurso especial provido.

Na construção dessa tese de incomunicabilidade dos bens durante a separação de fato, a doutrina propõe, como já fora comentado, que a regra constante do art. 1683 do Código Civil seja interpretada como cláusula geral, aplicável a qualquer regime de bens, embora esteja localizada, não nas disposições gerais do código, mas, sim, no capítulo que trata do regime de participação final nos aquestos.

É que o referido dispositivo legal determina sejam verificados os bens na data em que cessou a convivência, reforçando o entendimento de que a ruptura fática da relação pode servir como marco para o fim do regime de bens.

${ }^{55}$ STJ, REsp 555.771, Rel. Ministro Luis Felipe Salomão, Brasília, 05 mai. 2009. 
Guilherme Calmon Nogueira da $\mathrm{Gama}^{56}$ defende claramente a proposição em comento:

Cabe, pois, à doutrina e à jurisprudência interpretar que a regra constante do art. 1683 do Código Civil, na realidade, é uma disposição geral, aplicável, portanto, a todos os regimes de bens, e não apenas ao regime de participação final nos aquestos, sob pena de violação aos princípios e postulados constitucionais, além de ser clara hipótese de descumprimento do princípio do enriquecimento sem causa. A regra deve, pois, ser aplicada aos regimes de comunhão (parcial e universal), não se podendo mais cogitar do ingresso dos bens adquiridos, no período de separação de fato, à massa dos bens comuns do casal.

Maria Berenice Dias ${ }^{57}$, em perfeita coerência com suas convicções, também defende que: "a determinação de que o montante dos bens deve ser apurado na data em que cessou a convivência (CC 1.683), igualmente, estaria melhor alocada entre as disposições gerais".

Em tempo, cumpre registrar que o Projeto de Lei nº 6.960 de 2002 propunha o acréscimo de um parágrafo $1^{\circ}$ ao artigo 1.576 do Código Civil de 2002 para extinguir o regime de bens com a separação de fato, quando demonstrada a incomunicabilidade dos bens, a fim de se evitar o enriquecimento ilícito. No entanto, tal parágrafo não foi incorporado ao texto legal, encontrando-se o projeto arquivado na Câmara dos Deputados.

Ora, a partir do exposto, percebe-se que não são poucos os fundamentos, nem mesmo os adeptos, da tese de que a separação de fato, a despeito da ausência de previsão legal, deva ser considerada apta a cessar o regime de bens e o estado de mancomunhão, por ele, automaticamente imposto na constância do casamento.

\footnotetext{
${ }^{56}$ GAMA, Guilherme Calmon Nogueira da. Direito Civil: família. São Paulo: Atlas, 2008. p. 172 apud RITO, Fernanda Paes Leme Peyneau. Efeitos Patrimoniais da Separação de Fato. Disponível em: < http://www.ibdfam.org.br/?artigos\&artigo=586> Acesso em 14 abr. 2011.

${ }^{57}$ DIAS, Maria Berenice. Manual de Direito das Famílias. $6^{\mathrm{a}}$ ed.. p. 243.
} 


\section{V.V. Do direito à taxa de ocupação por uso exclusivo de imóvel na separação de fato}

Indubitável que se o casal já não pretende conviver, consequentemente não mais interessará aos cônjuges a manutenção de um patrimônio comum, o que torna incabível que um deles se utilize do patrimônio do outro sem a proporcional contraprestação. Ora, se não é do interesse de uma das partes dispor de seu patrimônio gratuitamente, a lei não deveria obrigá-la a tanto sem justa causa.

Assim é que, valendo-se de tais argumentos, a doutrina mais atualizada vem sustentando posicionamento em sentido diverso do que expõe a letra fria (e quase morta) da lei, tomando-se como certo que o regime de bens deve ser extinto a partir da separação de fato, cessando-se o estado de mancomunhão dos bens, e aplicando-se as regras de condomínio aos bens que forem de co-propriedade do ex-casal.

Com isso, seria possível a aplicação da taxa de ocupação por uso exclusivo de imóvel, mesmo durante a separação de fato, uma vez que o instituto do condomínio assegura a cada um dos condôminos igual direito, idealmente, sobre o todo e cada uma de suas partes. Cada condômino pode usar livremente a coisa, conforme seu destino, porém sem a exclusão dos demais, por terem os mesmos direitos sobre o bem.

Daí implica dizer que aquele que usufrui exclusivamente do imóvel de co-propriedade do ex-consorte deverá ressarci-lo na proporção de 50\% (cinqüenta por cento) da quantia correspondente a um aluguel, segundo os valores de mercado. 
É o que sustenta Maria Berenice Dias, corroborando todo o exposto:

Separado o casal, modo freqüente, fica o patrimônio na posse de somente um dos cônjuges. Sendo dois os titulares e estando somente um usufruindo do bem, impositiva a divisão de lucros ou o pagamento pelo uso, posse e gozo. Reconhecer que a mancomunhão gera um comodato gratuito é chancelar o enriquecimento injustificado. Assim, depois da separação de fato, mesmo antes do divórcio e independentemente da propositura da ação de partilha, cabe impor o pagamento pelo uso exclusivo de bem comum. (...) quem permanece no imóvel deve pagar pelo uso exclusivo do bem comum a título de aluguel. (...) Tal determinação tem cabimento não só no regime da comunhão universal de bens, mas em qualquer regime em que haja a comunhão de aquestos. ${ }^{58}$

58 DIAS, Maria Berenice. Conversão da separação de corpos em divórcio: salutar novidade. Disponível em: < http://www.mbdias.com.br/hartigos.aspx?110,23>. Acesso em 28 abr. 2011. 


\section{DA ATIVIDADE JURISDICIONAL COMO FONTE DO DIREITO: UMA ATIVIDADE INTERPRETATIVA E CRIATIVA}

A despeito desse novo posicionamento doutrinário, que vem angariando cada vez mais adeptos na doutrina, nossos tribunais ainda se vêem bastante arraigados ao arcaico e positivista entendimento de que o matrimônio somente acaba com a separação judicial ou com o divórcio, ignorando o enriquecimento sem causa que suas decisões acabam judicializando.

Conformando-se com o texto estático da lei, os magistrados, por vezes, acabam se influenciando pelo conservadorismo que o Direito costuma carregar, esquecendo-se que ele possui um intrínseco caráter social.

Com vistas para isso, Paulo Dourado de Gusmão ${ }^{59}$ sublinha:

O direito resulta, também, de reflexão intelectual, seja do legislador, seja do jurista, seja do juiz, provocada ou influenciada por fatos sociais: disciplinandoos, ordenando-os, incriminando-os. Lenta, gradual, é a introdução na ordem jurídica de novos princípios e de normas exigidos pelas novas situações histórico-sociais, devido a ser o direito, por natureza, conservador. Daí o ajustamento freqüente que existe entre a ordem jurídica e a ordem social: o direito em comparação com as demais formas de cultura (arte, moral, literatura, cinema, costumes, etc.), está sempre em atraso em relação às transformações sociais. A interpretação reduz, muitas vezes esse atraso, construindo, quando judicial, o direito jurisprudencial ( $\$ \S 80$ e 137), que pode conflitar com o codificado, ultrapassando, quantas vezes, a lei, como, por exemplo, as sentenças que, antes da intervenção do legislador, equiparou o concubinato à sociedade de fato para reconhecer o direito da concubina a participar do patrimônio do companheiro quando desfeita essa união. Hoje, o concubinato está legalizado, não dependendo mais de construção jurisprudencial o amparo à concubina abandonada, porque, pela constituição de 1988, foi transformado em entidade familiar sob a denominação de 'união estável'.

\footnotetext{
59 GUSMÃO, Paulo Dourado de. Introdução ao Estudo do Direito, 29a ed. Rio de Janeiro:
} Forense, 2001. p. 34. 
Não se está aqui a defender que os juízes tenham que tomar decisões contra legem, imiscuindo-se na esfera do Poder Legislativo. De fato, ao magistrado não cabe a função de legislar; mas compete a ele adaptar o que foi criado e positivado pelo legislador, através de uma atividade interpretativo-criativa, que encontra limites no Princípio da Separação dos Poderes, no Princípio Democrático e nos próprios parâmetros do ordenamento jurídico.

Ora, deve-se ter em mente que, ao contrário do que afirmava Montesquieu, o juiz não é apenas uma “boca da Lei”. Deveras, não há mais espaço, em um Estado Democrático de Direito, para uma visão tão simplista da atividade jurisdicional. Como bem observou Carnelutti ${ }^{60}$ : "o juiz é, ao mesmo tempo, mais ou menos conscientemente, juiz das partes e juiz do legislador".

Paulo Nader ${ }^{61}$ dá a sua contribuição ao tema:

É um dado da experiência que o Direito codificado não é suficiente, pelo simples enunciado das normas, para proporcionar ao juiz a solução necessária ao julgamento. O Direito Positivo apresenta-se mediante normas genéricas e abstratas, que não podem ser aplicadas com automatismo.

O autor $^{62}$ também acrescenta:

É princípio assente na moderna hermenêutica jurídica que os juízes devem interpretar o Direito evolutivamente, conciliando velhas fórmulas com as novas exigências históricas. Neste trabalho de atualização, em que a letra da lei permanece imutável e a sua compreensão é dinâmica e evolutiva, o juiz colabora decisivamente para o aperfeiçoamento da ordem jurídica. Ele não cria o mandamento jurídico, mas apenas adapta princípios e regras à realidade social.

\section{A respeito disso, Carmen Lúcia Silveira Ramos ${ }^{63}$ :}

${ }^{60}$ CARNELUTTI, Francesco. La Prueba Civil. 2 $2^{\mathrm{a}}$ ed.. Buenos Aires: Depalma, 1979 apud NETTO, Ernesto. A influência da jurisprudência no direito brasileiro. Disponível em: $<$ http://www.direitonet.com.br/artigos/exibir/5873/A-influencia-da-jurisprudencia-no-direitobrasileiro-Parte-II >. Acesso em 15 abr. 2011.

${ }^{61}$ NADER, Paulo. Introdução ao Estudo do Direito. p. 176.

${ }^{62}$ Ibid. p. 176. 
Neste sentido, a figura do judge made Law eventualmente é considerada incompatível com a tripartição de poderes, por supostamente invadir a esfera do Poder Legislativo e afrontar a certeza do direito, numa interpretação que revela com clareza as deficiências do modelo jurídico consagrado para cumprir com sua função de realização da justiça.

\section{Para o mesmo raciocínio, a supracitada autora ${ }^{64}$ aponta:}

O paradoxo contido neste entendimento se evidencia ainda mais quando se observa que o próprio sistema positivado, a despeito de suas insuficiências, permite decisões que repensam a função jurisdicional, mitigando a exegese dogmática do contido no ordenamento jurídico, através do reconhecimento de que a leitura das leis não deve ser formal e desvinculada da realidade, assim buscando uma interpretação mais compatível com o contexto social, e tentando atribuir ao Judiciário uma função de realização das aspirações de justiça, preservação da dignidade humana e do bem comum.

\section{Miguel Reale ${ }^{65}$, quanto a isso, também se manifesta:}

Os juízes são chamados a aplicar o Direito aos casos concretos, a dirimir conflitos que surgem entre indivíduos e grupos; para aplicar o Direito, o juiz deve, evidentemente, realizar um trabalho prévio de interpretação das normas jurídicas, que nem sempre são suscetíveis de uma única apreensão intelectual. Enquanto que as leis físico-matemáticas têm um rigor e uma estrutura que não dão lugar a interpretações conflitantes, as leis jurídicas, ao contrário, são momentos de vida que se integram na experiência humana e que, a todo instante, exigem um esforço de superamento de entendimentos contrastante, para que possam ser aplicadas em consonância com as exigências da sociedade em determinado momento e lugar.

\section{Ademais, comenta:}

A jurisprudência, muitas vezes, inova em matéria jurídica, estabelecendo normas que não se contêm estritamente na lei, mas resultam de uma construção obtida graças à conexão de dispositivos, até então considerados separadamente, ou, ao contrário, mediante a separação de preceitos por largo tempo unidos entre si. Nessas oportunidades, o juiz compõe, para o caso concreto, uma norma que vem completar o sistema objetivo do Direito. ${ }^{66}$

\footnotetext{
${ }^{63}$ RAMOS, Carmen Lucia Silveira. Família sem Casamento: De Relação Existencial de Fato a Realidade Jurídica. p. 19.

${ }^{64}$ Ibid. p. 19.

${ }^{65}$ REALE, Miguel. Lições Preliminares de Direito. $21^{\text {a }}$ ed.. São Paulo: Saraiva, 1994. p 167.

${ }^{66}$ Ibid. p. 167.
} 
O referido autor ${ }^{67}$ ainda critica: "se é um mal o juiz que anda à cata de inovações, seduzido pelas 'últimas verdades', não é mal menor o julgador que se converte em autômato a serviço de um fichário de arestos dos tribunais superiores".

Fredie Didier Jr. $^{68}$, ao defender que a jurisdição possui função criativa, cita Pontes de Miranda:

É como lembra Pontes de Miranda, para quem o princípio de que o juiz está sujeito à lei é algo de 'guia de viajantes', de itinerário, que muito serve, porém não sempre. Equivale a inserir-se, nos regulamentos de fábrica, lei de física, a que se devem subordinar as máquinas: a alteração há de ser nas máquinas. Se entendemos que a palavra 'lei' substitui a que lá deverá estar - 'direito' - já muda de figura. Porque direito é conceito sociológico, a que o juiz se subordina, pelo fato mesmo de ser instrumento da realização dele. Esse é o verdadeiro conteúdo do juramento do juiz, quando promete respeitar e assegurar a lei. Se o conteúdo fosse o de impor a 'letra' legal, e só ela, aos fatos, a função judicial não corresponderia àquilo para que foi criada: realizar o direito objetivo, apaziguar. Seria a perfeição, em matéria de braço mecânico do legislador, braço sem cabeça, sem inteligência, sem discernimento; mais: anti-social e - como a lei e a jurisdição servem à sociedade - absurda. Além disso, violaria, eventualmente, todos os processos de adaptação da própria vida social, porque só a ele, fosse a Ética, fosse a Ciência, fosse a Religião, fosse a Arte, respeitaria, se coincidissem com o papel escrito.

Em vista desse papel da jurisprudência, Carlos Maximiliano ${ }^{69}$ festeja a sua existência, citando Jean Cruet:

O juiz, esse ente inanimado, de que falava Montesquieu, tem sido na realidade a alma do progresso jurídico, o artífice laborioso do Direito novo contra as fórmulas caducas do Direito tradicional. Esta participação do juiz na renovação do Direito é, em certo grau, um fenômeno constante, podia-se dizer uma lei natural da evolução jurídica: nascido da jurisprudência, o Direito vive pela jurisprudência, e é pela jurisprudência que vemos muitas vezes o Direito evoluir sob uma legislação imóvel.

Faz-se novamente o empréstimo das palavras do supracitado autor:

\footnotetext{
${ }^{67}$ REALE, Miguel. Lições Preliminares de Direito. p. 168.

${ }^{68}$ JR., Fredie Didier, Curso de Processo Civil, $10^{\mathrm{a}}$ ed.. Editora JusPodivm, 2008. v. 1. p. 69.

${ }^{69}$ CRUET, Jean. A Vida do Direito. p. 26-27 apud MAXIMILIANO, Carlos, Hermenêutica $e$ Aplicação do Direito. $19^{\mathrm{a}}$ ed.. Rio de Janeiro: Forense, 2001. p. 39.
} 
Não pode o Direito isolar-se do ambiente em que vigora, deixar de atender às outras manifestações da vida social e econômica; e esta não há de corresponder imutavelmente às regras formuladas pelos legisladores. Se as normas positivas se não alteram à proporção que envolve a coletividade, consciente ou inconscientemente a magistratura adapta o texto preciso às condições emergentes, imprevistas. A jurisprudência constitui, ela própria, um fator do processo de desenvolvimento geral; por isso, a Hermenêutica se não pode furtar à influência do meio no sentido estrito e na acepção lata; atende às conseqüências de determinada exegese: quanto possível a evita, se vai causar dano, econômico ou moral, à comunidade. $\mathrm{O}$ intuito de imprimir efetividade jurídica às aspirações, tendências e necessidades da vida de relação constitui um caminho mais seguro para atingir a interpretação correta do que o tradicional apego às palavras, o sistema silogístico de exegese. ${ }^{70}$

Havendo um descompasso entre o Direito e as necessidades reais da sociedade, compete ao magistrado interpretar a lei de forma a solucionar os casos concretos da forma mais justa.

Atento a isso, o Ministro Sálvio de Figueiredo proferiu voto ${ }^{71}$ :

O fim da lei não deve ser a imobilização ou a cristalinização da vida, e sim manter contato íntimo com esta, segui-la em sua evolução e adaptar-se a ela. Daí resulta que o Direito é destinado a um fim social, de que deve o juiz participar ao interpretar as leis, sem se aferrar ao texto, às palavras, mas tendo em conta não só as necessidades sociais que elas visam disciplinar, como, ainda, as exigências da justiça e da eqüidade, que constituem o seu fim.

Ora, forçoso perceber que o embasamento na falsa idéia de que o legislador não comete erros, de que a lei em si se basta, de que ela deve ser seguida cegamente sem levar em conta a evolução social e a mudança dos valores nela envolvidos, é, no mínimo, uma acomodação do juiz, muitas vezes promotora de injustiças.

Daí porque Cássio Scarpinella Bueno também defende que a atividade jurisdicional do magistrado assume um caráter criativo:

A função do juiz, já não há mais como esconder esta realidade, é uma atividade criativa. Não se espera mais do juiz, apenas e tão-somente, que ele realize uma

\footnotetext{
${ }^{70}$ MAXIMILIANO, Carlos. Hermenêutica e Aplicação do Direito. p. 129.

${ }^{71}$ STJ, REsp. 4.987, Rel. Ministro Sálvio de Figueiredo, Brasília, 04 jun. 1991.
} 
reflexão quase-que-lógica ou quase-que-matemática sobre dadas premissas para concluir em um ou em outro sentido mas, bem diferentemente, de aceitar, na formação das suas próprias premissas e na sua conclusão, elementos diferentes, diversos, não levados em conta na evolução e sistematização do direito na primeira metade do século XIX, em especial na era das codificações. Já não se pode falar, em todos e em quaisquer casos, que a atividade do intérprete e do aplicador do direito seja meramente subsuntiva mas, bem diferentemente, sua função passa a ser concretizadora, no sentido de criadora do próprio direito a ser aplicado, justamente em função da complexidade do ordenamento jurídico atual. De uma atividade de mero conhecimento (um comportamento passivo), do fenômeno jurídico para sua aplicação, passa-se a uma atividade criadoravalorativa (um comportamento ativo), conscientemente criadora e valorativa do juiz. $^{72}$

No mesmo sentido, percebeu o desembargador Alves Braga ${ }^{73}$, do Tribunal de Justiça de São Paulo:

Mas o intérprete, ao contrário do legislador, não manipula ilusões. Vive realidades e deve buscar, no exame dessas realidades, o equilíbrio da ordem jurídica afetada. A ordem ética deve sempre ser observada e o exegeta não pode esquecer que as relações, causas e efeitos são constantes e inelutáveis.

Não por menos, afirma-se que jurisprudência é fonte do Direito. O estudo dos arestos, sem dúvida, serve ao progresso jurídico, pois prepara as reformas legislativas. Não raro, o tribunal, embora se conforme com a norma escrita, aponta-lhe os defeitos e a interpreta conforme os fatos e às necessidades que o caso concreto reclama, produzindo novo direito.

\footnotetext{
${ }^{72}$ BUENO, Cassio Scarpinella, Curso de Direito Processual Civil, $2^{\mathrm{a}}$ ed.. São Paulo: Saraiva, 2008. p. 65-66.

${ }^{73}$ TJ/SP, A.C. 947801, Rel. Desembargador Alves Braga, São Paulo, 03 mar. 1988.
} 


\section{DA JURISPRUDÊNCIA}

Decerto que a lei não previu a separação de fato como ensejadora do fim do regime de bens (art. $1571 \mathrm{c} / \mathrm{c}$ art. 1576, CC), mas, por outro lado, ela foi clara ao expressamente vedar o enriquecimento sem causa (art. 884, $\mathrm{CC})$.

Dado que a separação de fato é uma realidade e que dela surgem vários efeitos jurídicos, compete ao magistrado entender que a interpretação gramatical da lei, no que toca ao fim do regime dos bens, não deve prevalecer, sob pena de chancelar a vantagem patrimonial indevida que um cônjuge terá sobre o outro.

Todavia, o repertório de jurisprudência produzido por nossos tribunais a respeito do cabimento da taxa de ocupação por uso exclusivo de imóvel na separação de fato ainda reflete o apego dos magistrados ao texto positivado da lei, que, à conta disso, afastam a possibilidade do ressarcimento do cônjuge privado do uso e gozo de seu imóvel pelo cônjuge que, confortavelmente, se utiliza exclusivamente do bem comum sem qualquer contraprestação. Entendem que o uso do bem de propriedade da sociedade conjugal por apenas um dos consortes não gera direito à indenização ao outro, na medida em que a propriedade do imóvel também lhe pertenceria em mancomunhão. Ou seja, uma vez senhor do imóvel, seria incabível exigir-lhe contraprestação pelo seu uso.

À guisa de exemplificação, colacionam-se os seguintes julgados:

Arbitramento de Aluguel. Imóvel comum de cônjuges casados pelo regime da comunhão parcial de bens e separados de fato que passou a ser usado exclusivamente pelo cônjuge-varão. Ação objetivando o recebimento de alugueres desde a saída do cônjuge-mulher do lar conjugal com fulcro no artigo 1319 do Código Civil, que dispõe ser obrigação de cada condômino responder 
aos outros pelos frutos que percebeu da coisa e pelo dano que lhe causou. A Autora ingressou com a presente ação sem que fosse ultimada sua separação judicial, sendo que somente esta põe termo ao regime de bens instituído pelo casamento (artigo 1576 do Código Civil), não podendo, por conseguinte, valer-se das regras atinentes ao condomínio, que somente passam a incidir sobre o patrimônio comum, quando houver a separação judicial, da qual não resultar a partilha de bens ou, sendo estes partilhados, continuarem sob o uso exclusivo de apenas um dos consortes. Entendimento sufragado por reiterada jurisprudência do Superior Tribunal de Justiça. Eventuais desigualdades decorrentes do uso exclusivo por um dos cônjuges devem ser resolvidas através de ação de alimentos, na qual já é considerada a questão da moradia. Do momento em que o imóvel comunheiro foi locado pelo Réu a terceiro, passando a gerar frutos, estes devem ser rateados entre os cônjuges, não por força do disposto no artigo 1319 do C.C, mas segundo o que preceitua o artigo 1660 , inciso $\mathrm{V}$ do diploma civilista, na forma determinada na sentença. Sucumbência recíproca reconhecida por ter a Autora pedido o pagamento pelo Réu de taxa de ocupação desde a data em que a Suplicante se retirou do imóvel residencial do casal, tendo sido acolhido somente o pleito de recebimento dos frutos (alugueres) do imóvel, durante o período em que o mesmo permaneceu locado a terceiro. Conhecimento de ambas as Apelações, negando-se provimento à da Autora e provendo-se a do Réu. $^{74}$

APELAÇÃO CÍVEL. AÇÃO DE COBRANÇA. PEDIDO DE INDENIZAÇÃO, A TÍTULO DE ALUGUERES, PELO USO GRATUITO DE IMÓVEL COMUM, PELO EX-MARIDO DA AUTORA, A PARTIR DA DATA DA SEPARAÇÃO JUDICIAL. IMPOSSIBILIDADE. A PERCEPÇÃO DE ALUGUERES, NO CASO CONCRETO, DEVE OCORRER SOMENTE A PARTIR DO TRÂNSITO EM JULGADO DA SOBREPARTILHA DE BENS. Até a efetivação da divisão do patrimônio do casal, os bens permanecem em mancomunhão, de forma que, neste período, o uso exclusivo do imóvel, por um dos consortes, não dá ensejo à indenização, pelo outro. A circunstância de ter permanecido o imóvel comum na posse exclusiva de um dos cônjuges após a separação judicial, autoriza cobrança de aluguéis pelo outro consorte, mas tão somente depois de ultimada a sobrepartilha dos bens, quando consolidada a quota parte de cada cônjuge. Direito ao recebimento de aluguéis, que se estende até a data da homologação do acordo em ação de imissão de posse, em valor a ser arbitrado em sede de liquidação de sentença. Sentença reformada em parte. Sucumbência redimensionada. DERAM PARCIAL PROVIMENTO. UNÂNIME. ${ }^{75}$

DIREITO PROCESSUAL CIVIL. SEPARAÇÃO JUDICIAL LITIGIOSA. DISSOLUÇÃO DE SOCIEDADE DE FATO. PARTILHA DE BENS. IMÓVEL COMUM. USO POR UM DOS CÔNJUGES INDENIZAÇÃO AO COPROPRIETÁRIO. FRUTOS CIVIS. COMUNICABILIDADE. I - Predomina o entendimento jurisprudencial de que, dissolvido o vínculo conjugal, o coproprietário que permanecer na posse privativa do bem deve indenizar o outro pelo uso exclusivo da coisa comum. Assim, a permanência de um dos cônjuges no imóvel, após a separação judicial e partilha, autoriza o outro a ser indenizado pelo uso e gozo do que não usufruiu.II - Os frutos civis do trabalho de cada cônjuge ou de ambos, no regime da comunhão parcial de bens, previsto no

\footnotetext{
${ }^{74}$ TJ/RJ, A.C. 0036154-39.2005.8.19.0001, Rel. Desembargador Mario Robert Mannheimer, Rio de Janeiro, 10 jul. 2007.

${ }^{75}$ TJ/RS, A. C. 70029677291, Rel. Desembargador Nelson José Gonzaga, Rio Grande do Sul, 18 nov. 2010.
} 
Código Civil de 1916, entram na comunhão, devendo ser partilhados de forma proporcional.III - Apelação parcialmente provida. Maioria. ${ }^{76}$

CASAMENTO. REGIME DE COMUNHÃO UNIVERSAL DE BENS. DIREITO AO USO DESTES. - A COMUNHÃO RESULTANTE DO MATRIMONIO DIFERE DO CONDOMINIO PROPRIAMENTE DITO, PORQUE NELA OS BENS FORMAM A PROPRIEDADE DE MÃO COMUM, CUJOS TITULARES SÃO AMBOS OS CONJUGES. - CESSADA A COMUNHÃO UNIVERSAL PELA SEPARAÇÃO JUDICIAL, O PATRIMONIO COMUM SUBSISTE ENQUANTO NÃO OPERADA A PARTILHA, DE MODO QUE UM DOS CONSORTES NÃO PODE EXIGIR DO OUTRO, QUE ESTIVER NA POSSE DE DETERMINADO IMOVEL, A PARTE QUE CORRESPONDERIA A METADE DA RENDA DE UM PRESUMIDO ALUGUEL, EIS QUE ESSA POSSE, POR PRINCIPIO DE DIREITO DE FAMILIA, ELE EXERCE EX PROPRIO JURE. - RECURSO CONHECIDO PELA LETRA "C" E PROVIDO. ${ }^{77}$

Por outro lado, despontam, em nossas cortes, magistrados atentos à realidade social, filiando-se à doutrina contemporânea e atualizada que defende o cabimento da taxa de ocupação por uso exclusivo de imóvel durante a separação de fato, em virtude da impossibilidade de fruição do imóvel por um dos cônjuges por ele estar sendo ocupado exclusivamente pelo outro consorte.

Essa oxigenação jurisprudencial, que vem representando uma nova tendência nos tribunais brasileiros, em atenção à vedação do enriquecimento sem causa, pode ser ilustrada a partir dos seguintes arestos:

Coisa comum - A separação de fato se assemelha à separação judicial para o fim de possibilitar que o cônjuge cobre aluguel daquele que está usufruindo exclusivamente do bem comum - Ação procedente - Valor devido apurável em execução - Recurso provido. ${ }^{78}$

AGRAVO DE INSTRUMENTO. PROCESSUAL CIVIL E FAMÍLIA. SEPARAÇÃO JUDICIAL E ALIMENTOS. - DECISÃO EXARADA EM AUDIÊNCIA. RETIDO INADEQUADO, NA ESPÉCIE. INTERLOCUTÓRIA COM CARGA BASTANTE PARA A IDENTIFICAÇÃO DE LESÃO GRAVE E DE DIFÍCIL REPARAÇÃO. RECURSO APROPRIADO CONHECIDO. QUEBRA DO SIGILO BANCÁRIO DO CÔNJUGE VARÃO. TRABALHADOR AUTÔNOMO/EMPRESÁRIO E INDÍCIOS DE

\footnotetext{
${ }^{76}$ TJ/DF, A. C. 20020110056957, Rel. Desembargadora Vera Andrighi, Distrito Federal, 14 nov. 2007.

${ }^{77}$ STJ, REsp 3.710, Rel. Ministro Antônio Torreão Braz, Brasília, 21 jun. 1995.

${ }^{78}$ TJ/SP, A.C. 4.941.774, Rel. Desembargadora Berreta da Silveira, São Paulo, 20 mar. 2007.
} 
CONFUSÃO PATRIMONIAL. MEDIDA EXCEPCIONAL RECOMENDÁVEL. - QUEBRA DE SIGILO BANCÁRIO DE EMPRESA. PERSONALIDADES JURÍDICAS DISTINTAS. AUSÊNCIA DE INDÍCIOS ROBUSTOS DE ABUSO DA PESSOA JURÍDICA. VIOLAÇÃO DESNECESSÁRIA. - USO EXCLUSIVO DE IMÓVEL DO CASAL PELO MARIDO. FIXAÇÃO DE INDENIZAÇÃO À VIRAGO. POSSIBILIDADE, NO CASO. IMPEDIMENTOS CONCRETOS AO USO COMUM E SAÍDA INVOLUNTÁRIA DO LAR. PENHORA SOBRE O BEM. IRRELEVÂNCIA. DESVALORIZAÇÃO DO IMÓVEL. AUSÊNCIA DE PROVA. TEMÁTICA RECHAÇADA. - DECISÃO REFORMADA. RECURSO CONHECIDO E PROVIDO PARCIALMENTE PARA INDEFERIR A QUEBRA DE SIGILO FRENTE À PESSOA JURÍDICA.

- Desafiam agravo retido as decisões lançadas em audiência (CPC, art. 523, §3º). Todavia, se a interlocutória possuir o condão de proporcionar, mesmo que em potência, lesão grave e de difícil reparação, apropriado o agravo de instrumento.

- Em razão do confuso cenário probatório, da dificuldade de produção de provas acerca dos ganhos do varão (empresário), e tratando-se de causa atinente ao Direito de Família, mostra-se recomendável o abrandamento dos rigores legais e a quebra do sigilo bancário do marido, a fim de que se possa mensurar com um mínimo de propriedade as possibilidades econômico-financeiras deste.

- Tendo, em princípio, personalidade jurídica distinta de seu sócio, desaconselhável a violação ao sigilo bancário de pessoa jurídica quando ausentes indícios concretos de abuso do ente fictício e o esclarecimento fático possa ser alcançado mediante outras medidas.

- "É possível a cobrança de alugueres pelo uso exclusivo de imóvel em condomínio quando houver resistência do ocupante à fruição concomitante do imóvel. Igualmente factível essa cobrança, quando a simples ocupação do bem por um dos consortes representar impedimento de cunho concreto, ou mesmo psicológico, à utilização simultânea pelos demais condôminos, circunstância exemplificada na utilização de imóvel comum por cônjuge após a separação e antes da partilha, situação que representa óbvio impedimento prático ao usufruto comum do bem." (STJ. Resp $n^{\circ} \odot$ 622.472/RJ, rel ${ }^{\mathrm{a}}$. Min ${ }^{\mathrm{a}}$. NANCY ANDRIGHI, j. em 19.8.2004).

- Ausente prova bastante, não há acolher argumento segundo o qual evento climático severo fez o imóvel comum perder valor comercial. ${ }^{79}$

Destaca-se um julgado, a partir da transcrição de um excerto da sua

fundamentação, que expõe muito bem a argumentação que se defende:

Indiscutível a possibilidade de se exigir o pagamento de aluguel proporcional do condômino que utiliza a coisa com exclusividade, em detrimento dos demais, com fundamento no princípio que veda o enriquecimento sem causa. Embora a lei não explicite, tal situação é admitida de longa data pela doutrina e jurisprudência. (Carvalho Santos, J. M. Código Civil brasileiro interpretado. Rio de Janeiro, Freitas Bastos, 1943, v. VIII, Monteiro, Washington de Barros, Curso de Direito Civil, vol. 4, p. 208, JTJ 122/87 e 206/27)

\footnotetext{
${ }^{79}$ TJ/SC, Ag. Inst. 20090566251, Rel. Desembargador Juiz Henry Petry Junior, Santa Catarina, 09 fev. 2010.
} 
O presente caso, porém, não trata de condomínio comum, mas sim de mancomunhão, ou condomínio de mão comum, expressão utilizada para designar o estado de bens do casal, durante o casamento, ou separado de fato.

Na mancomunhão os bens não pertencem a cada um dos cônjuges em metades ideais: pertencem ao casal. (Pontes de Miranda, Tratado de Direito de Família, atualizado por Vilson Rodrigues, Campinas, Bookseller, 2001, p. 230 apud Rel. Antonio Vilenilson, TJSP, A.C. 248.610.4/8). Integram um patrimônio, ou seja, um complexo de relações jurídicas, contendo ativos e passivos. Disso decorre a distinção com o condomínio, onde há a possibilidade de disposição de parte ideal da coisa.

Embora não seja pacífica nos Tribunais de Justiça, a possibilidade de indenização pelo uso exclusivo do bem em estado de mancomunhão, compartilho o entendimento de Maria Berenice Dias, que mesmo antes da separação judicial e independentemente da propositura da ação de partilha, admite o pagamento pelo uso exclusivo de bem comum, sob pena de chancelar o enriquecimento injustificado (Manual de Direito das Famílias, $4^{\mathrm{a}}$ Ed., Ed. RT, pg. 296).

Parece-me cada vez mais que a separação de fato do casal provoca efeitos jurídicos, pois não mais há a instituição do casamento, mas apenas sua carcaça jurídica, desprovida de conteúdo. Parece violar a cláusula geral que veda o enriquecimento sem causa, assim, que durante longa tramitação de uma ação de separação, possa um dos cônjuges usar e fruir o patrimônio comum, em detrimento do outro.

Sob essa ótica, nada justifica que o ex-cônjuge usufrua com exclusividade de imóvel comum sem remunerar a ex-esposa pela parte que lhe cabe. ${ }^{80}$

(Grifos nossos)

Ex vi das decisões acima arroladas, forçoso concluir que a evolução do Direito de Família, em sintonia com a realidade social brasileira, impõe ao magistrado valer-se de uma hermenêutica sistemática e teleológica das normas, de modo a poder constatar que a separação de fato é capaz de por fim ao regime de bens e, consequentemente, ao estado de mancomunhão dos mesmos, e, a partir disso, reconhecer, com espeque no princípio que veda o enriquecimento sem causa (art. 884, CC), a possibilidade da aplicação da taxa de ocupação por uso exclusivo de imóvel na separação de fato.

\footnotetext{
${ }^{80}$ TJ/SP, Ag. Inst. 6784384300, Rel. Desembargador Francisco Loureiro, São Paulo, 15 out. 2009.
} 


\section{CONSIDERAÇÕES FINAIS}

Do casamento emanam conseqüências patrimoniais ou econômicas que interessam ao direito. Em que pese não seja a família organizada com fins patrimoniais, certo é que a sociedade conjugal tende a gerar um patrimônio comum necessário à consecução de seus fins.

A essência das relações econômicas entre casados reside nos regimes de bens, que nada mais são do que o conjunto de regras determinante das relações pecuniárias que resultam do casamento.

Repousam os regimes matrimoniais que prevêem a comunhão de bens sobre dois pilares: o animus societatis do casal e a mútua contribuição visando à formação de um patrimônio comum. Ausentes esses pilares - tal como ocorre na separação de fato -, afigura-se injustificável a imposição do estado de indivisão patrimonial que se conhece como estado de "mancomunhão de bens" ${ }^{81}$

Nesse sentido, é a data da separação de fato que se impõe como marco temporal final do regime de bens. Isto porque, segundo a boa doutrina $^{82}$ "o fim da vida em comum leva à cessação do regime de bens, seja ele qual for, porquanto já ausente o ânimo socioafetivo, real motivação da comunicação patrimonial."

Não obstante isso, a lacuna na lei sobre a separação de fato e a interpretação literal dos arts. 1575 e 1576 do Código Civil têm levado à formação de uma jurisprudência conservadora segundo a qual apenas a separação judicial e o divórcio podem por termo ao regime de bens. A consagração de tal entendimento conduz, lamentavelmente, a situações de

\footnotetext{
${ }^{82}$ DIAS, Maria Berenice. Manual de Direito das Famílias. $6^{\text {a }}$ ed.. p. 298.
} 
enriquecimento sem causa de um dos cônjuges, qual seja, aquele que, após a separação, passa a se utilizar exclusivamente do imóvel de propriedade do casal.

Trata-se de hipótese de locupletamento indevido de um dos excônjuges que reclama a reparação do outro consorte, impedido que foi de exercer plenamente o seu direito de propriedade sobre o bem comum. Cumpre, assim, ao primeiro, ser onerado com quantia correspondente a 50\% (cinqüenta por cento) do valor de locação do imóvel, a ser paga em favor do ex-cônjuge que dele se retirou por força da separação de fato.

Por ser insuficiente o tratamento legal dado à questão da taxa de ocupação de imóvel na hipótese da separação de fato, cabe ao Judiciário invocar o princípio que veda o enriquecimento sem causa para, conferindo uma interpretação sistemática e teleológica à legislação que rege a matéria, considerar findo o regime de bens à data da ruptura fática da conjugalidade, assim realizando a sua função primordial de promoção da Justiça. 


\section{BIBLIOGRAFIA}

ARAUJO, Eduardo Pereira de. Evolução histórica dos institutos da separação e do divórcio no direito brasileiro e a Emenda Constitucional $n^{o}$ 66/2010. Disponível em <http://www.conteudojuridico.com.br/?artigos\&ver=2.29383\#_edn5>. Acesso em 12 mar. 2011.

BRANDÃO, Vanessa Caús. Do Casamento Religioso com Efeitos Civis e o Novo Código Civil. Disponível em: <http://jus.uol.com.br/revista/texto/2662/do-casamento-religioso-comefeitos-civis-e-o-novo-codigo-civil/1>. Acesso em 10 mai. 2011.

BUENO, Cassio Scarpinella, Curso de Direito Processual Civil, $2^{\mathrm{a}}$ ed.. São Paulo: Saraiva, 2008. 573 p.

CAHALI, Yussef Said. Divórcio e separação. $10^{\mathrm{a}}$ ed.. São Paulo: Editora Revista dos Tribunais, 2002. 1376 p.

COSTA, Henrique Araújo. Reexame de Prova em Recurso Especial: A Súmula 7 do STJ, cap. 15. Disponível em: $<$ http://www.arcos.org.br/livros/reexame-de-prova-em-recurso-especial-asumula-7-do-stj/capitulo-i-fato-e-direito/2-teorias-de-diferenciacao-entrefato-e-direito/b-etapa-dogmatica/b-impossibilidade-de-separacao-entrefato-e-direito>. Acesso em 24 abr. 2011.

DIAS, Maria Berenice. Direito de Família e o Novo Código Civil. $2^{\mathrm{a}}$ ed.. Belo Horizonte: Del Rey, 2002. 295 p.

. Manual de Direito das Famílias. $6^{\mathrm{a}}$ ed. São Paulo: Editora Revista dos Tribunais, 2010. 672 p.

. Manual de Direito das Famílias. $7^{\mathrm{a}}$ ed. São Paulo: Editora Revista dos Tribunais, 2010.671 p. - Conversão da separação de corpos em divórcio: salutar novidade. Disponível em: <http://www.mbdias.com.br/hartigos.aspx?110,23>. Acesso em 28 abr. 2011.

FARIAS, Cristiano Chaves de; ROSENVALD, Nelson. Direito das Famílias. 2a ed.. Rio de Janeiro: Lumen Juris, 2010. 945 p. 
GAMA, Guilherme Calmon Nogueira da. Separação de Fato e Ética no Direito de Família: Revista da Faculdade de Direito da UERJ. v. 13/14. 2005/2006. p. 11-34.

GONTIJO, Segismundo. Do Regime de Bens na Separação de Fato. Revista dos Tribunais, 735, jan/1997. p. 131-160.

GOMES, Orlando, Direito de Família. $5^{\text {a }}$ ed.. Rio de Janeiro: Forense, 1983. $447 \mathrm{p}$.

GUSMÃO, Paulo Dourado de. Introdução ao Estudo do Direito, $29^{\mathrm{a}}$ ed. Rio de Janeiro: Forense, 2001. 459 p.

JR., Fredie Didier, Curso de Processo Civil, $10^{\mathrm{a}}$ ed.. Editora JusPodivm, 2008. v. 1.594 p.

LIMA, Maria Aparecida Singh Bezerra de. A Separação de Fato entre os Cônjuges $e$ os seus Efeitos. Disponível em: www.cesumar.br/pesquisa/periodicos/index.php/.../article/.../349. Acesso em 25 abr. 2011.

MAXIMILIANO, Carlos, Hermenêutica e Aplicação do Direito. $19^{\mathrm{a}}$ ed.. Rio de Janeiro: Forense, 2001. 342 p.

NADER, Paulo. Introdução ao Estudo do Direito. $26^{\mathrm{a}}$ ed.. Rio de Janeiro: Forense, 2006. p. 390.

Curso de Direito Civil: Direito de Família. $2^{\mathrm{a}}$ ed. Rio de Janeiro: Forense, 2008. v. 5.569 p.

NETTO, Ernesto. A influência da jurisprudência no direito brasileiro. Disponível em: <http://www.direitonet.com.br/artigos/exibir/5873/Ainfluencia-da-jurisprudencia-no-direito-brasileiro-Parte-II $>$. Acesso em 15 abr. 2011.

PEREIRA, Caio Mário da Silva. Instituições de Direito Civil. 20ª ed.. Rio de Janeiro:Forense, 2009. v. 4. 395 p.

de janeiro: Forense, 2009. v. 5. 623 p.

PEREIRA, Sérgio Gischkow. Tendências Modernas do Direito de Família. Revista dos Tribunais $n^{\circ} 628$, fev/1988. p. 19-39. 
RAMOS, Carmen Lucia Silveira. Família sem Casamento: De Relação Existencial de Fato a Realidade Jurídica. Rio de Janeiro: Renovar, 2000. $193 \mathrm{p}$.

REALE, Miguel. Lições Preliminares de Direito. $21^{\mathrm{a}}$ ed.. São Paulo: Saraiva, 1994. $381 \mathrm{p}$.

RITO, Fernanda Paes Leme Peyneau. Efeitos Patrimoniais da Separação de Fato. Disponível em: <http://www.ibdfam.org.br/?artigos\&artigo=586>. Acesso em 14 abr. 2011.

RODRIGUES, Sílvio. Direito Civil: Direito de Família. 28ª ed.. São Paulo: Saraiva, 2004. v. 6. 433p.

TEPEDINO, Gustavo et al. Código Civil Interpretado: Conforme a Constituição da República. Rio de Janeiro: Renovar, 2006. v. 2. 909 p.

VENOSA, Sílvio de Salvo. Direito Civil: Direito de família. $7^{\text {a }}$. ed.. São Paulo: Atlas, 2007, 459 p.

WAMBIER, Teresa Arruda Alvim. Meação de Patrimônio Adquirido por um dos Cônjuges Durante a Separação de Fato. Revista de Processo $\mathrm{n}^{\mathbf{0}} 70$, 1993. V. 18. p. 166-174.

\section{Jurisprudência}

STF, RE nº 77204, Rel. Ministro Leitão de Abreu, Brasília, 26 mar. 1976.

STF, Ag. Reg. em Ag. Instr. 182458, Rel. Ministro Marco Aurélio, Brasília. 04 mar. 1997

STJ, Ag. Rg. nos Edcl. no Ag. Rg. no Ag. 727485/RJ, Rel. Ministro Felix Fischer, Brasília, 20 nov. 2006.

STJ, REsp 679525, Rel. Ministro Luiz Fux, Brasília, 12 mai. 2005.

STJ, REsp. 64.352, Rel. Ministro Waldemar Zveiter, Brasília, 26 set. 1995.

TJ/SP, A.C. 2486104800, Rel. Desembargador Antonio Vilenilson, São Paulo, 02 out. 2007.

STJ, EDcl no Rec. Ord. em MS, Rel. Ministro Fernando Gonçalves, Brasília, 14 dez. 2004. 
STJ, REsp 555.771, Rel. Ministro Luis Felipe Salomão, Brasília, 05 mai. 2009.

STJ, REsp. 4.987, Rel. Ministro Sálvio de Figueiredo, Brasília, 04 jun. 1991.

TJ/SP, A.C. 947801, Rel. Desembargador Alves Braga, São Paulo, 03 mar. 1988.

TJ/RJ, A.C. 0036154-39.2005.8.19.0001, Rel. Desembargador Mario Robert Mannheimer, Rio de Janeiro, 10 jul. 2007.

TJ/RS, A. C. 70029677291, Rel. Desembargador Nelson José Gonzaga, Rio Grande do Sul, 18 nov. 2010.

TJ/DF, A. C. 20020110056957, Rel. Desembargadora Vera Andrighi, Distrito Federal, 14 nov. 2007.

TJ/SP, Ag. Inst. 6784384300, Rel. Desembargador Francisco Loureiro, São Paulo, 15 out. 2009. 